\title{
Current Developments in Mobilization of Hematopoietic Stem and Progenitor Cells and Their Interaction with Niches in Bone Marrow
}

\author{
Rudolf Richter ${ }^{a, b} \quad$ Wolfgang Forssmann ${ }^{a}$ Reinhard Henschler ${ }^{c}$ \\ a Department of Internal Medicine, Clinic of Immunology, Hanover Medical School, Hanover, Germany; \\ ${ }^{b}$ MVZ Labor PD Dr. Volkmann \& Kollegen, Karlsruhe, Germany; \\ c Swiss Red Cross Blood Transfusion Services Zurich and Chur, Zurich, Switzerland
}

\section{Keywords}

Hematopoietic stem cell · Bone marrow · Mobilization . Stem cell niche

\section{Summary}

The clinical application of hematopoietic stem and progenitor cells (HSPCs) has evolved from a highly experimental stage in the 1980s to a currently clinically established treatment for more than 20,000 patients annually who suffer from hematological malignancies and other severe diseases. Studies in numerous murine models have demonstrated that HSPCs reside in distinct niches within the bone marrow environment. Whereas transplanted HSPCs travel through the bloodstream and home to sites of hematopoiesis, HSPCs can be mobilized from these niches into the blood either physiologically or induced by pharmaceutical drugs. Firstly, this review aims to give a synopsis of milestones defining niches and mobilization pathways for HSPCs, including the identification of several cell types involved such as osteoblasts, adventitial reticular cells, endothelial cells, monocytic cells, and granulocytic cells. The main factors that anchor HSPCs in the niche, and/or induce their quiescence are vascular cell adhesion molecule(VCAM)-1, CD44, hematopoietic growth factors, e.g. stem cell factor (SCF) and FLT3 Ligand, chemokines including CXCL12, growth-regulated protein beta and IL-8, proteases, peptides, and other chemical transmitters such as nucleotides. In the second part of the review, we revise the current understanding of HSPC mobilization. Here, we discuss which mechanisms found to be active in HSPC mobilization correspond to the mechanisms relevant for HSPC interaction with niche cells, but also deal with other mediators and signals that target individual cell types and receptors to mobilize HSPCs. A multitude of questions remain to be addressed for a better understanding of HSPC biology and its implications for therapy, including more comprehensive concepts for regulatory circuits such as calcium homeostasis and parathormone, metabolic regulation such as by leptin, the significance of autonomic nervous system, the consequences of alteration of niches in aged patients, or the identification of more easily accessible markers to better predict the efficiency of HSPC mobilization.

(c) 2017 S. Karger GmbH, Freiburg

\section{Introduction}

Hematopoietic stem and progenitor cells (HSPCs) produce more than 100 billion mature blood cells per day in a healthy individual which carry out functions such as oxygen transport, immunity, hemostasis, or tissue surveillance and remodeling. Over the last 30 years, transplantation of HSPCs has become an accepted treatment for patients with a number of hematological malignancies and nonmalignant diseases. Attempts to decipher microenvironmental mechanisms of HSPC maintenance, quiescence, proliferation, and differentiation induction reach back to work in the 1970s by Dexter et al. [1] who demonstrated the co-existence of HSPCs and stromal cells in long-term bone marrow cultures. Using their in vitro model [1] and the results of in vivo studies in mice [2], it was already postulated that distinct niches exist within bone marrow, where quiescent and slowly dividing HSPCs reside in close interaction with mesenchymal, endothelial or bone cells.

\section{KARGER}

Fax +497614520714
(๑) 2017 S. Karger GmbH, Freiburg
Prof. Dr. Reinhard Henschler

Blood Transfusion Service SRC Zurich \& Chur Rüttistrasse 19

8952 Zurich, Switzerland

reinhard.henschler@blutspende-gr.ch 
As will be shown in this review, these hypotheses have proven correct over the next three decades, with bone marrow microenvironment found to be composed of different types of niche cells that form regulatory units, limiting the entry of HSPCs into the cell cycle, and ensuring a life-long repopulation of the hematopoietic system by a limited number of HSPCs that can crosstalk, maintain, and regenerate the HSPC pool over several life spans [3, 4]. The discovery in the late 1980s that hematopoietic growth factors, especially granulocyte colony-stimulating factor (G-CSF) and granulocyte-macrophage colony-stimulating factor (GM-CSF) can be employed clinically to mobilize HSPCs into the blood $[5,6]$ challenged the exploration of the mechanisms which govern mobilization of HSPCs into the blood, and which regulate their engraftment after transplantation. In the following, we report on the status of the current developments in this field and delineate further work needed to reconcile our knowledge on the function of the HSPC niche with the concepts of stem cell mobilization.

\section{HSPC Niches and Their Cell Types}

\section{Osteoblasts - the First Recognized Site of an HSPC Niche}

Experiments by Ray Schofield and Bryan Lord conducted to localize the colony-forming unit-spleen (CFU-S) in murine femur marrow space indicated a preferential localization of CFU-S near the bone surface. [7]. Benayahu et al. [8,9] demonstrated that stromal cells that support hematopoiesis often carry osteogenic markers and function, and that hematopoiesis is supported by osteoblastic cells. After the description of hematopoietic colonystimulating factors, experiments by the group of Taichman and Emerson [10-12] in the 1990s showed that osteoblasts produce hematopoietic growth factors like G-CSF and hepatocyte growth factor (HGF) upon contact with CD34+ HSPC or stimulation with either parathyroid hormone (PTH) or the locally produced $\mathrm{PTH}$ related protein (PTHrP) through the $\mathrm{PTH} / \mathrm{PTHrP}$ receptor (PPR) [10-12]. It was observed that in mice, the transplanted HSPCs preferentially locate in the endosteal region of bone marrow [13]. Osteoblasts supporting HSPCs have a distinct phenotype of N-cadherin + CD45- (SNO) and are regulated by bone morphogenetic protein (BMP) [14]. Mice conditionally deficient in BMP receptor type IA (BMPRIA) displayed increases in the numbers of SNO cells, which correlated with an increase in the numbers of HSPCs, indicating that the size of the HSPC pool might be indirectly regulated [14].

\section{The Osteoblastic Niche - Externally Regulated?}

In 2003, Calvi et al. [15] published a landmark paper on the role of osteoblasts in hematopoiesis. They used a mouse model carrying a constitutively active PPR under the control of the $\alpha 1$ (I) collagen promoter, resulting in an increase of osteoblastic cells in bone marrow. This was associated with an increase in lineage-negative, long- term repopulating stem cells at the interface between marrow and bone [15]. Immunohistochemical analyses indicated that osteoblasts expressed CXCL12, SCF, IL- 6 and the Notch ligand, Jagged 1 (Jag1) [15]. Notch seemed to be functional, since increased Notch signaling increased numbers of HSPCs without affecting mature hematopoietic cells, whereas blocking Notch signaling by inhibition of Notch cleavage decreased numbers of long-term repopulating HSPCs [15-17]. Moreover, wild-type bone marrow stromal cells cultured in the presence PTH gained capacity to maintain long-term bone marrow-initiating cells (LTC-IC), and application of PTH to mice over 4 weeks increased HSPCs with bone marrowrepopulating activity [15]. Thus, PTH can regulate HSPC proliferation by influencing relevant growth signals for HSPCs on osteoblastic stromal cells.

\section{Osteoblasts Maintain HSPCs in a Quiescent State through Soluble and Membrane-Localized Factors}

Whereas a role for IL-6 and SCF expressed on osteoblasts was already known [12], the contribution of osteoblasts to HSPC maintenance and their quiescence was consolidated by Arai et al. [18] who showed that osteoblasts express angiopoietin-1, which binds to the Tie2 receptor on HSPCs to support HSPCs quiescence, adhesion of HSPCs to bone areas, and maintenance of HSPCs in culture. Osteoblasts were also found to express thrombopoietin (TPO), which activates the MPL receptor that is expressed on quiescent HSPCs in the bone marrow. TPO/MPL interaction upregulates beta1-integrin and cyclin-dependent kinase inhibitors in HSPCs and was shown to induce quiescence of LT-HSPC, whereas inhibition of the TPO/MPL pathway with anti-MPL-neutralizing antibody reduced the number of quiescent HSPCs [19, 20].

The next significant factor in the regulation of primitive HSPC proliferation in the osteoblastic niche is osteopontin, which restricts primitive cell expansion in the bone marrow niche [21]. In the absence of osteopontin, stromal Jag1, angiopoietin-1, and Notch1 receptor expression on human CD34+ cells is significantly increased [22]. Increased numbers of LTC-IC could be cultivated on stromal cells from osteopontin-deficient mice [21]. Thus, angiopoietin-1, TPO, and osteopontin are involved in the maintenance of the HSPC compartment and protection of HSPCs from myelosuppressive stress, involving osteoblasts as a stromal cell compartment.

\section{Transplanted HSPCs Enter Directly into the Osteoblastic Niche}

In vivo imaging analysis using a multi-photon imaging techniques in c-kit receptor-deficient mice, which lack HSPCs and therefore enable analysis for HSPC engraftment, confirmed that transplanted primitive HSPCs located preferentially to sites near the bone-lining osteoblasts [23]. Localization of HSPCs into the osteoblastic niche was dependent on high calcium concentrations, since in calcium-sensing receptor (CaR) knockout mice, trans- 
Fig. 1. Hematopoietic stem cell niches can be provided by different cell types. The different cell types are characterized by expression of distinct molecules and are found in the endosteal, sinusoidal HSPC niche or near the small arterioles. Stromal cells in the sinusoidal niche are characterized by expression of Nestin, CD146, STRO-1, HS2, HS3, HS4. SDF-1/CXCL12, Leptin receptor. VEcadherin(Cdh5)-expressing endothelial cells are also found in the sinusoidal niche. CAR cells are characterized by expression of high amounts of SDF-1/CXCL12. Connexin 43 and 45 expressing Nestin+ MSCs as well as osteoblasts reveal electromechanical coupling with $\beta$-adrenergic nerves. In the endosteal niche, osteoblasts and especially SNO osteoblasts as well as CAR cells were identified. NG2 expressing cells encircling small arterioles in endosteal bone marrow are associated with quiescence HSPCs.

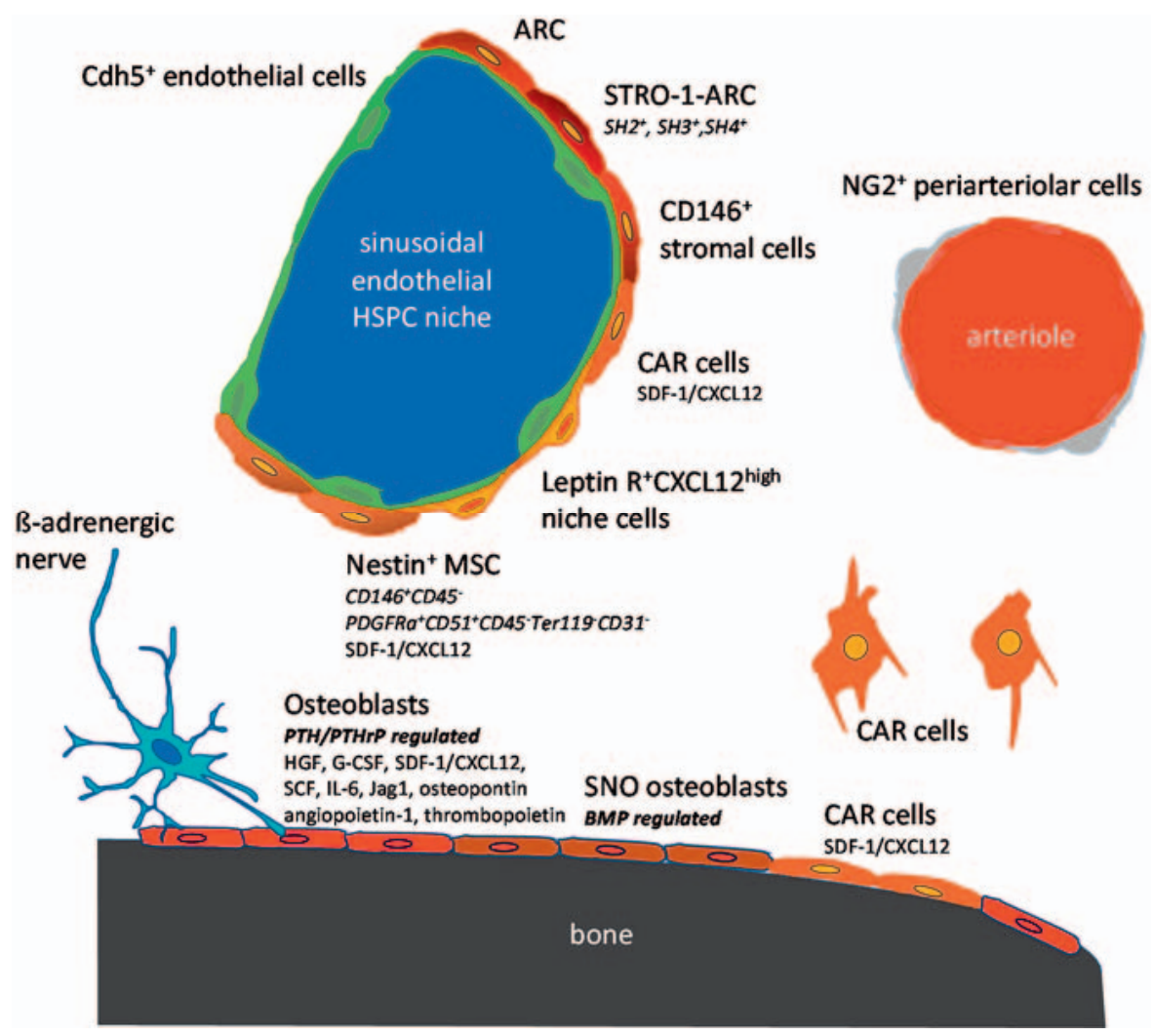

planted HSPCs did not locate into osteoblastic niche areas [24]. This indicates that the ionic mineral content of the niche can guide the preferential localization of adult mammalian hematopoiesis to bone. Homing of HSPCs to the osteoblastic niche was only found after irradiation of mice, but not without irradiation, explaining the need for conditioning in an attempt to 'open' marrow space, i.e., niches for transplanted HSPCs. Improved in vivo imaging techniques were used for these studies which make use of fluorescence markers to tag HSPCs as well as stromal compartments [25]. In these models, transplanted HSPCs were found to primarily locate in the vicinity of vasculature and near $\mathrm{N}$-cadherin + pre-osteoblastic cells [26]. A summary of osteoblastic cells acting as niche cells is given in figure 1 .

\section{The Reticular Fibroblastic Cells: Candidate No. 2 for the HSPC Niche Cell}

Ground-breaking work in the 1970s and 1980s by Lichtman et al. [27] had identified adventitial reticular cells (ARCs) and sinusoidal endothelial cells in close proximity with nests of hematopoiesis within bone marrow. Such fibroblast-like cells were also shown to be part of the adherent fraction of bone marrow cells, which forms an hematopoiesis-supporting adherent layer when bone marrow is placed into long-term culture conditions [1,28]. A direct isolation of ARCs was first made possible by Simmons et al. [29] who identified the Stro-1 antibody, recognizing an ARC population. The Stro- 1 cells were later shown to also contain cells with osteogenic differentiation potential [30]. At the same time, the group of Caplan [31] showed that three surface markers, SH2, SH3 and SH4, also recognize a fibroblast-like population in bone marrow which supports hematopoiesis and which can differentiate into various mesenchymal cell lineages such as osteoblasts, chondrocytes, and adipocytes. This cell population was also termed MSCs, for 'marrow stromal cells' or 'mesenchymal stem cells'. Further milestones in the discovery of the potency and the ubiquity of MSCs come from their direct isolation from perivascular areas upon their expression of CD146 and negativity for CD45 [32], the identification and possibility of tagging of MSCs by positivity for Nestin [33], and the possibility to directly isolate fully competent HSPC-supporting MSCs from mice by a marker combination PDGFRa+ CD51+ CD45- Ter119- CD31- [34].

\section{Perivascular Location of the HSPC Niche and the CXCL12- Abundant Reticular Cell}

Kiel et al. [35] showed that HSPCs could be highly enriched using so-called SLAM family member cell surface markers CD150, CD248 and CD48, in combination with classical HSPC markers in the mouse, Sca-1, lineage (lin) and c-kit [35]. This enabled them to distinguish between long-term repopulating HSPCs, which also form the quiescent HSPC pool, from short-term repopulating HSPCs and multi-potent HSPCs with high proliferative potential but lacking self-renewal capacities. Many HSPCs were found to be associated with sinusoidal endothelium in spleen and bone mar- 
row, although some HSPCs were also associated with endosteum. This work formed the basis for the model of a sinusoidal endothelial HSPC niche, in addition to the osteogenic niche.

The expression of the chemokine receptor CXCR4 on HSPCs and of its ligand CXCL12 on stromal cells in bone marrow has been recognized to be of pivotal relevance for hematopoiesis and engraftment of transplanted HSPCs [36]. Immunohistochemical analysis of bone marrow sections using fluorescence-labelled probes in combination with bromodesoxyuridine to pulse chase non-dividing (i.e. quiescent) HSPCs showed that most HSPCs in mice were found in close contact with the cells expressing high amounts of CXCL12, which they termed CXCL12-abundant reticular (CAR) cells [37-39]. CAR cells either surrounded sinusoidal endothelial cells or were located near the endosteum. Nestin was established as a marker of a small subpopulation of non-hematopoietic MSCs, which are spatially associated with HSPCs and adrenergic nerve fibers $[33,40]$. CXCL12 expression was $>50$-fold higher in Nestin-GFP+ than in Nestin GFP- cells, and 10-fold higher than in primary osteoblasts. Depletion of Nestin+ MSCs in mice resulted in a 50\% reduction of immature HSPCs and a $90 \%$ reduction of HSPC homing to the bone marrow [33]. Moreover, administration of PTH induced proliferation of Nestin+ MSCs, their differentiation into osteoblasts, and an increase of the HSPC pool $[15,33,41]$.

Innervation of CAR cells by the sympathetic nervous system was confirmed by the high expression of connexins 43 and 45 in Nestin $^{+}$MSCs, indicating their electromechanical coupling with $\beta$-adrenergic nerve terminals, supporting the fact that $\beta 3$ adrenoceptor activation induced depletion of HSPCs [42-44]. Compared to Nestin- MSCs, Nestin+ MSCs highly express HSPC maintenance genes SCF/c-kit Ligand, IL-7 and vascular cell adhesion molecule-1 (VCAM-1) and, as a counter-regulator of HSPC maintenance, osteopontin.

The function of CAR cells has been elegantly investigated by Omatsu et al. [45] using a transgenic mouse model regulating expression of CXCL12. When CAR perivascular cells were depleted by a cell-specific knock-in strategy into the CXCL12 locus, HSPCs were reduced in numbers and became more quiescent, suggesting a key role for CXCL12 presented on perivascular mesenchymal CAR cells in controlling HSPC proliferation [45]. Arteriolar perivascular cells which express the mesenchymal cell marker NG-2 (Cspg4), also maintain HSPC quiescence [46]. Whether CXCL12-expressing perivascular cells are mainly found in the arteriolar wall or around sinusoids remains unclear. Recently, the stem cell antigen 1 (Sca-1) was described as a relevant surface marker for the identification of ARC-type niche cells [47]. These authors showed that Sca1+ mesenchymal progenitors exist in bone marrow of mice, which can give rise to CARs, whereas their Sca1- counterparts give rise to osteoprogenitors, underlying the previously described concept of a common mesenchymal stromal progenitor cell for the adult hematopoietic niche. Figure 1 illustrates markers and locations of several identified HSPC niche cell types.

\section{Possible Roles of Endothelial Cells in the HSPC Niche}

As shown in figure 1, ARCs are positioned in very close contact to endothelial cells. This has prompted investigation into endothelial cells also contributing to HSPC niche signals. Kobayashi et al. [48] and Hooper et al. [49] showed that, during chemotherapy, sinusoidal vessels including arterioles and sinusoidal endothelial cells are dose-dependently damaged, and that the vascular-endothelial growth factor receptor 2 (VEGFR2) is essential in their regeneration and engraftment of transplanted HSPCs. Using adenoviral E4ORF1 gene-transduced, human sinusoidal primary (E4ORF1) endothelial cells in serum- and cytokine-free long-term cultures, Butler et al. [50] could show that direct cellular contact of murine HSPCs with these E4ORF1+ endothelial cells increased repopulation potential and self-renewal of HSPCs through the Notch ligands Jag1, Jag2, Dll4, and Dll1. In line with this, endotheliumtargeted human delta-like 1 enhances the regeneration and homing of human cord blood stem and progenitor cells. Disruption ofVEGFR2 and VE-cadherin-dependent angiogenic signaling pathways (which are significant for endothelial cell survival) by monoclonal antibodies for 3 days disrupted Notch signaling in hematopoietic cells, decreased the frequency of LT-HSPCs, and favored their differentiation [51]. Vice versa, the conditional deletion of Jag1 in endothelial cells resulted in active cycling of a significant portion of the HSPC pool, a profound decrease in hematopoiesis, and a premature exhaustion of the adult HSPC pool [52]. In further work, depletion of pleiotrophin has been shown to deplete HSPCs and to interfere with their homing to endothelial niches [53]. Finally, conditional deletion of SCF in endothelial cells and leptin receptor-expressing perivascular cells resulted in decreased bone marrow HSPC numbers [54, 55].

'Deep imaging' of bone marrow vascular structures showed that $85 \%$ of long-term repopulating HSPCs, identified by $a$-catulin-GFP+c-kit+ expression, were within $10 \mu \mathrm{m}$ of a sinusoidal blood vessel and in contact with leptin receptor+ and CXCL$12^{\text {high }}$-expressing niche cells [56]. Moreover, deletion of the endothelial cell-specific adhesion molecule, E-selectin induces increased HSPC quiescence, suggesting that endothelial cells can also regulate HSPC proliferation [57]. These results indicate that in addition to endothelial-specific regulators, some niche signals defined to operate in osteoblasts and ARCs may also be active in endothelial cells.

\section{Attachment of HSPCs to Endothelial Cells}

Recent work demonstrated that more than $94 \%$ of HSPCs in the bone marrow marked by expression of HoxB5 are found in an abluminal position of the vessel and are directly attached to VEcadherin(Cdh5)-expressing endothelial cells [58]. These HoxB5marked HSPCs represent between $7 \%$ and $35 \%$ of phenotypic HSPCs when classic markers are used - for instance Lin- Sca1+ c-Kit+ CD150+ CD48-, suggesting that this compartment remains heterogeneous and that fractions of HSPCs may also behave differ- 
ently. Thus, endothelial cells may be intricately involved in supporting HSPCs in their niche, and a triangular interaction may exist between HSPCs, ARCs and endothelial cells (fig. 1).

\section{Macrophages, Megakaryocytes, and the HSPC Niche}

Bone marrow HSPCs are also found in contact with macrophages or megakaryocytes, in addition to endothelial cells and perivascular cells. Bone marrow macrophages release CXCL12/ SDF1, which is a potent chemoattractant of HSPCs, and osteocalcin (Bglap); which both act to support osteoblast survival and retention of HSPCs in their niche [59, 60]. Depletion of CD169+ (Siglec1) macrophages in mice leads to decreased retention of HSPCs in the mesenchymal (ARC) niche in the bone marrow, and consequently HSPCs are mobilized in the bloodstream [59]. Owing to the intimate cross-talk between osteoblasts and macrophages in the regulation of HSPC maintenance, it is difficult to dissociate these cell types as being distinct HSPC supportive niches. Winkler et al. [61] showed that G-CSF induced a depletion of endosteal macrophages, which was associated with a suppression of osteoblast function and a HSPC mobilization.

HSPCs are also found in direct contact with megakaryocytes. Megakaryocytes normally secrete cell cycle regulators such as thrombopoietin (TPO), transforming growth factor $\beta 1$ (TGF- $\beta 1$ ), and CXCL4, which keep HSPCs in the $\mathrm{G}_{0}$ phase of the cell cycle [62-64]. However, under the chemotherapeutic stress of the small molecule 5-fluoruracil, megakaryocytes secrete fibroblast growth factor 1 (FGF-1) and down-regulate TGF- $\beta 1$, stimulating the expansion of HSPCs [64]. These findings suggest that megakaryocytes might contribute to the HSPC niche.

\section{Aging of HSPCs and Their Niches}

A number of data suggests that HSPC niches change over lifetime. It has been noted that adipogenesis is enhanced in aged bone marrow, which might promote myelopoiesis over lymphopoiesis and impair HSPC function. Along with this is the finding that young HSPCs in an aged environment tend to produce slightly more myeloid cells than in a young environment (for review see [65]). Aging also involves decreases in osteoprogenitor cells associated with endothelial cells in the bone marrow, a decrease in numbers of PDGFR $\beta+/ \mathrm{NG} 2+$ perivascular cells of arterioles and of endothelial cells, resulting in reduced production of SCF $[65,66]$. Interestingly, leukemic cells may also regulate the physiology of the HSPC niche. This fact is underlined by studies showing that neutralization of SCF which is secreted by leukemic cells inhibits migration of CD34+ progenitors into malignant niches, resulting in normalized CD34+ cell numbers, and restoration of CD34+ cell mobilization in leukemic mice [67]. Together, these data show that HSPC niches are plastic and may change during the aging process or in the presence of malignant transformation.

\section{Mobilization of HSPCs: Convergence with Mechanisms Constituting HSPC Niches?}

Mobilized peripheral blood stem cells (PBSCs) have evolved as the main cellular source for HSPC transplants in patients over the last 25 years. Recently, the one-millionth human HSPC transplant was celebrated. When PBSCs began to be used clinically in the early 1990s, little was known about the mechanisms by which HSPCs are mobilized. It was known that HSPCs are found in blood in states of infection, after chemotherapy, and after administration of hematopoietic colony-stimulating factors, with G-CSF being the most efficient and practicable factor. In the meantime, PBSCs have been better characterized. Main features of PBSCs in comparison to bone marrow-derived HSPCs are their higher motility and more efficient engraftment, their relatively lower levels of c-kit, integrin VLA-4 and the CXCR4 receptor, and the fact that they are more quiescent than their bone marrow counterparts $[68,69]$.

\section{Role of Adhesion Receptors}

The significance of VLA-4/VCAM-1, VLA-5/fibronectin and CD44/hyaluronan/osteopontin interactions between HSPCs and stromal cells, for retention of HSPCs in the bone marrow niche was suggested by experiments using function-blocking anti-VLA-4, anti-VLA-5, or anti-CD44 antibodies, all resulting in liberation of HSPCs and their mobilization into the blood [70,71]. The release of HSPCs from stromal cells within the bone marrow is affected by the proteolytic degradation of VCAM-1 by elastase and cathepsin G, and of CXCL12 by neutrophil proteases [72]. Importantly, cleavage was also shown to occur with CXCR4 $[73,74]$. Also, shedding of membrane-bound SCF by matrix metalloproteinase 9 (MMP-9) has been found to contribute to HSPC mobilization [73, 75]. These discoveries pointed to a common 'end pathway' in HSPC mobilization, after stimulation with G-SCF, but also after stimulation with other stimuli such as chemokines or chemotherapy.

\section{ARC/CAR Cells}

A central mechanism that regulates HSPC-directed migration from blood to bone marrow and retention in the bone marrow niches involves activation of the CXCR4 receptor on the HSPCs by CXCL12/SDF-1 expressed on different subsets of ARCs including the CAR cells [37], reticular Nestin- GFP+ mesenchymal stem and progenitor cells (MSPCs) [33], human reticular CD146+ MSPCs [32] and perivascular reticular leptin receptor+ cells [55]. CXCL12 is secreted by these cells and decorated to the extracellular matrix inducing a CXCL12 gradient and induction of HSPC adhesion to the bone marrow niches $[37,76,77]$. During ontogeny, CXCL12 is required for colonization of the bone marrow with HSPCs [78]. Interference with CXCL12/CXCR4, such as by conditional deletion of CXCR4 or CXCL12 in mice, resulted in a reduced retention of HSPCs in the bone marrow and in dramatically increased migra- 
a

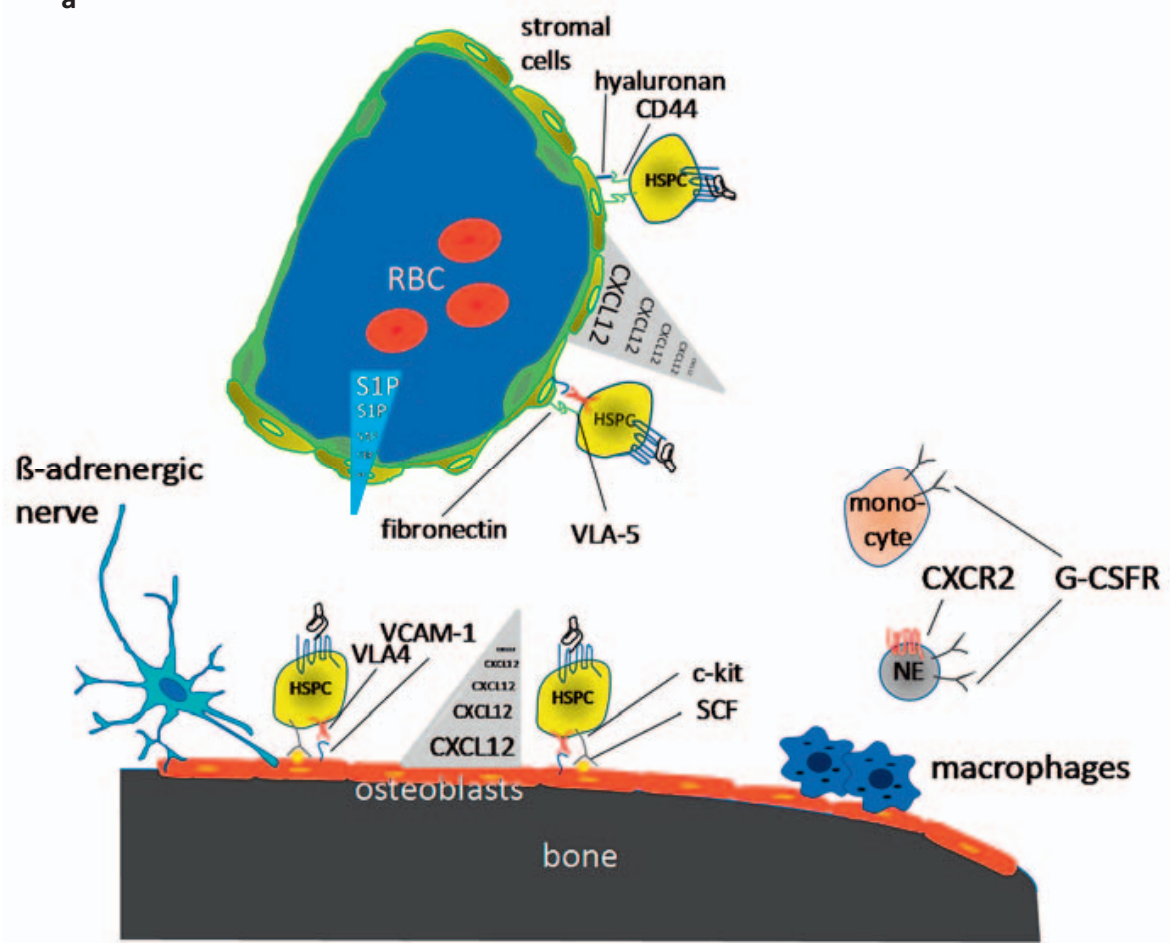

Fig. 2. Mechanisms of G-CSF induced mobilization of HSPCs. a During steady-state homeostasis, HSPCs are predominantly retained in the bone marrow niche via stromal/HSPC interactions regulated by chemokines (especially SDF-1/CXCL12) expressed by mesenchymal stromal progenitor cells, endothelial cells and osteoblasts. Chemokines induce expression of adhesion molecules VLA-4, VLA-5, and CD44. b G-CSF induces expansion of neutrophils in the bone marrow, which release proteases. These proteases inactivate chemokines, adhesion molecules and growth factors such as CXCL12, VCAM-1, and SCF. G-CSF administration depletes macrophages which suppress osteoblast function with reduced CXCL12, SCF, and VCAM-1 expression. Furthermore, G-CSF induces $\beta 3$-adrenoceptor activation, which down-regulates CXCL12, SCF, and VCAM-1 expression in osteoblasts and sinusoidal stromal cells, supporting HSPC mobilization. Transiently increased concentrations of S1P and probably increased concentrations of active CXCL12 in blood plasma induce migration of HSPCs in blood. The impact of further chemotactic factors and SDF-1-CXCR4 axis priming factors has still to be elucidated.

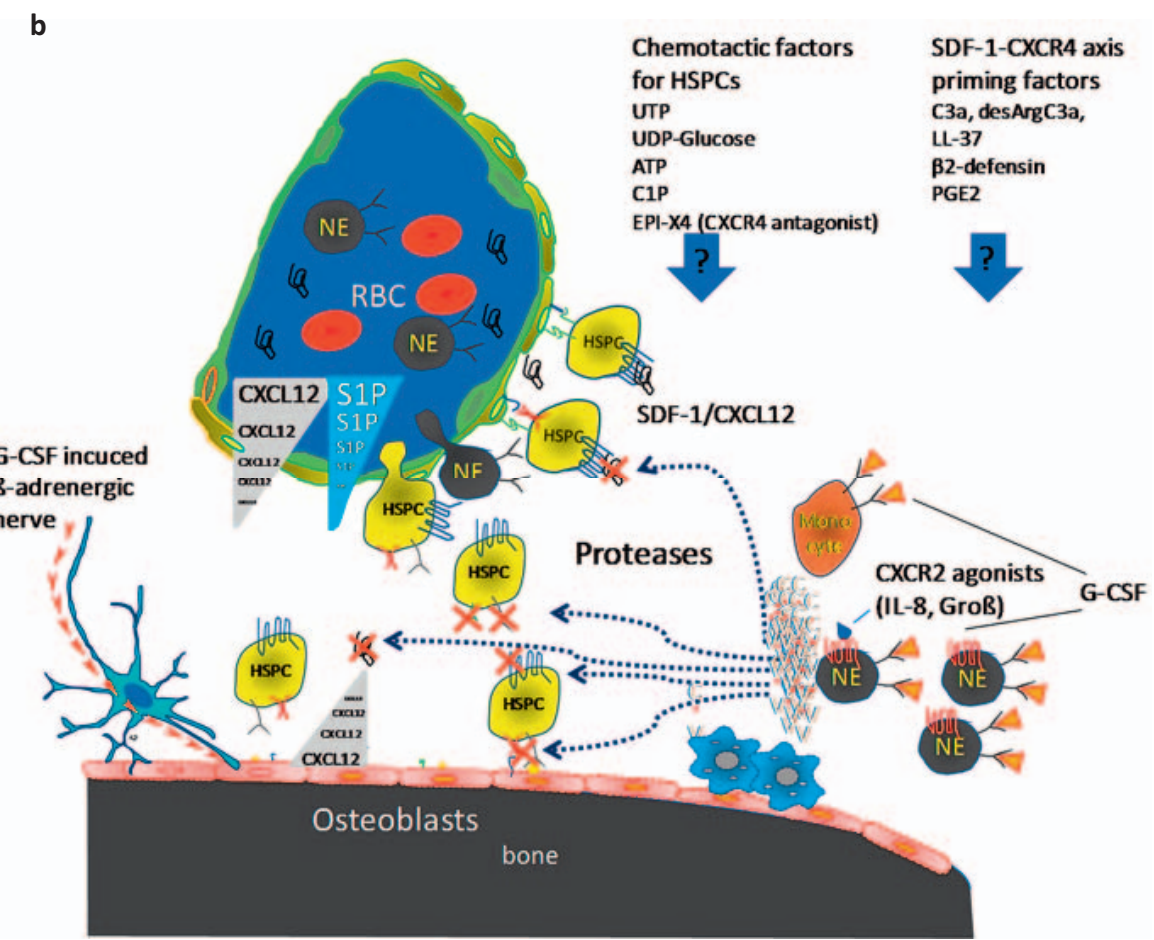

tion of HSPC numbers into the peripheral blood and into spleen of mice $[79,80]$. CXCL12/SDF-1 itself activates cell-surface integrins VLA-4, VLA-5 [81, 82] and the adhesion molecule CD44 [83], indicating further consequences of disrupting other relevant adhesion mechanisms of HSPCs to cells of the HSPC niche. Relevant elements of the mobilization signal cascade are delineated in figure 2a,b.
Growth Factors and Chemokines Involved in HSPC Mobilization

Absence of c-Met signaling in HSPCs results in strong impairment of the HSPC egress from the bone marrow to blood, whereby blocking of CXCR4 prevented G-CSF-induced c-Met activation and HSPC mobilization [84, 85]. Furthermore, inhibition of c-Met expression and activity also inhibited in vitro migration of HSPCs to- 
wards a gradient of CXCL12 [84]. Downregulation of CXCL12/ SDF-1 in the bone marrow was also observed upon administration of SCF and FLT3-L $[86,87]$. In contrast, chemokines may also induce HSPC mobilization, albeit rapidly, in a direct manner and independently of CXCL12/CXCR4. This is the case with growth-regulated protein beta [88], and with IL-8. The latter is dependent on the serine protease inhibitor, serpinla [89]. Epidermal growth factor has been shown to inhibit G-CSF-induced HSPC mobilization [90]. Administration of VEGF followed by treatment of mice with AMD3100 resulted in mobilization of both, endothelial progenitor cells and stromal progenitor cells, but suppressed HSPC mobilization [91].

Circadian rhythms have been clearly shown to influence the distribution of HSPCs between bone marrow and peripheral blood with peaking $5 \mathrm{~h}$ after the initiation of light and reaching a nadir 5 $\mathrm{h}$ after darkness, as a result of sympathetic innervation of ARC stromal cells [43]. Treatment with G-CSF influences expression of clock genes in peripheral blood cells and may be useful in analyzing the 'clock stage' of harvested HSPCs [92].

\section{Pharmacological Inhibition of HSPC-Niche Interactions Leading to Mobilization}

AMD3100/plerixafor is a synthetic organic molecule of the bicyclam class, originally developed as an anti-HIV drug. It was found to rapidly mobilize HSPCs in various animal models, and in patients it is used as a supportive measure in cases where G-CSFmediated HSPC mobilization fails to induce sufficient numbers of HSPCs [93-95]. Another CXCR4 inhibitor, T-140, mobilizes HSPCs and also erythroblasts in murine models and displays synergy with G-CSF [96]. To date, more chemical inhibitors have been developed as a means to mobilize HSPCs from bone marrow into blood and are in part clinically tested [97]. Another way, which is also followed clinically, is mobilization of HSPCs by functionblocking antibodies or chemicals directed against integrins, mediating HSPC adhesion to niche cells. Firategrast, an $\alpha 4 \beta 1$ and $\alpha 4 \beta 7$ integrin inhibitor $(\alpha 4 \beta 1 / 7)$ has been shown to disrupt HSPC retention in the postnatal hematopoietic niche and to synergistically interact with the CXCR4 inhibitor AMD3100 [98]. Vedolizumab, a humanized monoclonal antibody against the $\alpha 4 \beta 7$ integrin, is available and has been tested in phase I in another context [99]. Other inhibitors are discovered in preclinical experiments. Reduction in plasma CXCL12 levels, accompanied by reduced HSPC egress, has been observed in mice treated with vedolizumab, a humanized monoclonal antibody against the $\alpha 4 \beta 7$ integrin receptors. The rapid mobilization by AMD3100 does not only regulate CXCL12 levels, but also induces MMP-9 and uPA activation [77, 100]. Interference with integrins is also reached by a substance named BOP (N-(benzenesulfonyl)-L-prolyl-L-O-(1-pyrrolidinylcarbonyl)tyrosine) which targets integrins $\alpha 9 \beta 1 / \alpha 4 \beta 1$ [101]. Interestingly, it also enhanced AMD3100-induced HSPC mobilization.

The Rac small GTPases expressed in hematopoietic progenitors and HSPCs have been found to be intricately involved in HSPC mobilization, and application of a specific inhibitor of Rac activity (but not Cdc42 or RhoA activity) may be used for rapid HSPC mobilization $[102,103]$. Recently, it was shown that Rac1 activation leads to reversible conformational change in human CXCR4 that potentiates SDF-1/CXCR4 signaling, implying reciprocal cross-talk between these signaling pathways [104]. Finally, diabetic mice show increased HSPC retention in the bone marrow and poor HSPC mobilization upon G-CSF [105]. Down-modulation of CXCL12/SDF-1 with G-SCF is absent in these animals. The defect could be salvaged by application of AMD-3100 and shows that mobilization of HSPCs may be influenced by diseases outside the hematopoietic system. On the other hand, increased chemotactic activity was found in murine and human plasma upon mobilization with G-CSF and chemotherapy, which in vitro was inhibited by a functional CXCR4 antibodies [106]. In mice, G-CSF- and chemotherapy induced production of this chemotactic activity from the bone marrow, liver, and spleen, indicating that an increased concentration of active SDF-1/CXCL12 is circulating in blood during mobilization of HSPCs [106].

\section{Osteoblastic Cells}

Osteoblastic cells have been under study of alterations in the HSPC niche during mobilization. As with ARCs, osteoblastic cells secrete $\beta$-AR agonists to down-regulate osteolineage expression of CXCL12, VCAM-1, and SCF [107]. SCF/c-kit ligand, IL-7, and VCAM-1 and, as a counter-regulator of HSPC maintenance, osteopontin are all selectively down-regulated during mobilization by G-CSF treatment or after $\beta 3$ adrenoreceptor activation [40]. Since G-SCF stimulates $\beta$-adrenergic sympathetic nervous activity, this provides evidence for a signaling chain inducing HSPC mobilization. However, three recent studies in mice genetically altered by a conditional deletion of the CXCL12 or SCF genes in mature osteoblasts using Ocn-Cre or the $2.3-\mathrm{kb}$ fragment of the rat collagen 1a (Col2.3)-Cre did not result in HSPC mobilization, but rather a restriction in B-cell lymphopoiesis [55, 108, 109], casting some doubt on the relevance of the above-mentioned gene regulation in this cell type [110]. On the other hand, in transgenic mice expressing the human diphtheria toxin receptor under the control of the Dmp1 gene promoter, treatment with diphtheria toxin which kills osteocytes in these mice, abolished HSPC mobilization in response to G-CSF [111]. Figure 2a,b shows the functions of osteoblastic cells in HSPC mobilization.

\section{Endothelial Cells}

Endothelial cells have been shown to be the main constitutive source of infection-induced expression of G-CSF in bone marrow [112]. It is therefore likely that these signals are related to or part of mobilization of HSPCs. A mutually exclusive distribution of EPHB4 receptors in bone marrow sinusoids and ephrin B2 ligands in hematopoietic cells prompted investigation of the role of interactions of these molecules in HSPC mobilization. Blockade of the 
EPHB4/ephrin B2 signaling pathway in mice was shown to reduce mobilization of HSPCs and other myeloid cells to the circulation [113]. Endothelial cells also play a role in secreting CXCL12/SDF-1 into the circulation upon stimulation with AMD3100 [77]. Interestingly, the role of endothelial cells in egress of HSPCs into the circulation is in many parts non-deciphered [86]. Of note, neutrophils permeabilize the sinusoid endothelial barrier in the bone marrow, as shown by transmission electron microscopy studies [114]. However, disruption of the bone marrow endothelial barrier is prominent during repetitive G-CSF stimulations, indicating that the endothelial cells do function as a target of G-CSF during HSPC mobilization [115].

\section{Granulocytes}

G-CSF treatment was shown to induce a robust expansion of neutrophils within the bone marrow, and they are the first cells to egress from the bone marrow during mobilization after G-CSF administration [116]. All three classical types of HSPC mobilization by external stimuli, i.e. G-CSF, chemotherapy and chemokines, are disrupted if the G-CSF receptor is absent in neutrophilic granulocytes, but not if it is absent in hematopoietic progenitor cells despite normal hematopoiesis [117]. G-CSF receptor has been shown to be required for chemotherapy- - or IL-8-induced, but not flt3Linduced mobilization [117]. Serine proteases and metalloproteinases released by neutrophilic granulocytes have been shown to cleave VCAM-1 [72], c-kit [73], SCF [75] and CXCL12/SDF-1 [85] from stromal niche cells or HSPCs and include neutrophil elastase, cathepsin G and MMP-9 (figure 2 A,B). These proteases are released by neutrophils as a last step during the mobilization process after G-CSF, and during mobilization with chemokines or chemotherapy, leading to rapid egress of HSPCs and progenitors into the circulation.

\section{Monocytic Cells}

Granulocyte colony-stimulating factor receptor (G-CSFR) has been also been reported to signal in monocytes to mobilize HSPCs into the blood stream, by suppressing the supportive role of osteoblasts and disrupting the CXCR4/CXCL12 axis [60] (se figure 2 $\mathrm{A}, \mathrm{B})$. Moreover, monocytic cells are involved through the complement cascade, which is activated by radio- and chemotherapy [118], thereby liberating the complement factors C3a and desArgC3a anaphylatoxin $[119,120]$. Complement factor 3 (C3) knockout mice, under steady-state conditions, are hematologically normal but display a significant delay in hematopoietic recovery subsequent to irradiation or transplantation of wild-type HSPCs. C3 complement factors increase responsiveness of HSPCs to CXCR4/CXCL12 axis [121-123], also suggesting an involvement of the classical complement activation pathway in HSPC mobilization. Moreover, complement factor 5(C5)-deficient mice showed impaired mobilization of HSPCs [114].
A factor which is likely dependent on monocytes and which regulates HSPC mobilization is nitric oxide. Mobilization studies in inducible nitric oxide synthase(iNOS)-/- mice indicated that iNOS is a negative regulator of hematopoietic cell migration and prevents egress of HSPCs into peripheral blood during mobilization [124].

\section{Sphingolipids and Nucleotides in HSPC Mobilization}

In addition to CXCL12 (SDF-1) and its receptor CXCR4 a number of other chemoattractants, inducing migration of HSPCs are found. These include the sphingolipids sphingosine-1-phosphate (S1P) $[100,125-128]$ that couple to G protein-coupled sphingosine 1-phosphate receptor 1 (S1P1), and ceramide-1-phosphate (C1P) which acts via an hitherto unknown receptor $[127,129]$. Moreover, extracellular nucleotides, such as adenosine triphosphate (ATP) or uridine triphosphate (UTP) [130] and divalent cation $\mathrm{Ca}^{2+}$ and the $\mathrm{CaR}$, and $\mathrm{H}^{+}[131,132]$ regulate adhesion molecules on the surface of the HSPCs as well as on certain cells of the stem cell niches. Whereas the cells of origin of these molecules are in many cases not clear as yet, their action includes the mediation of engraftment (after transplantation), adhesion (under steady state), and mobilization (after its induction).

\section{S1P}

S1P and the receptor S1P1 are suggested to regulate HSPC steady-state egress and mobilization from the bone marrow. S1P is produced by mature red blood cells [133-135] and activated platelets [136], leading to micromolar S1P concentrations in blood, mostly bound to albumin and high-density lipoproteins (HDL) [137]. Since only low concentrations of S1P are detectable in solid tissues, a constant S1P concentration gradient between the bone marrow and blood important for the constant steady-state release of HSPCs has been suggested [133-137]. This idea is supported by the finding that inhibition of S1P1 receptor with the specific inhibitor FTY720 decreases steady-state mobilization of HSPCs into the bloodstream [100]. In line with this, over-expression of S1P1 receptor in HSPCs increased S1P-mediated migration, and a reduction of CXCR4 surface expression with a significant inhibition of in vitro CXCL12/SDF-1 induced migration and reduced HSPC homing potential to the bone marrow [138]. Also, transiently increased S1P plasma concentrations are observed during mobilization with G-CSF or AMD3100 [100], probably due to increased hemolysis by activating the complement cascade and the membrane attack complex [127], suggesting that S1P is involved in release of HSPCs during mobilization [100]. Increased bone marrow concentrations of S1P also induce CXCL12/SDF-1 secretion from bone marrow Nestin+ MSCs, and a reduced release of HSPCs into the blood [100].

A second S1P receptor, S1PR3, expressed on HSPCs is suggested to be involved in the retention of HSPCs in the bone marrow niche. Inhibition or knockout of S1PR3 results in mobilization of HSPCs into blood circulation, whereby S1PR3 antagonism suppresses bone marrow and plasma CXCL12/SDF-1 concentrations 
[139]. On the other hand, S1PR3 antagonism increases AMD3100 induced mobilization, indicating a synergy between S1PR3 and CXCR4 pathways.

\section{C1P}

After lethal irradiation, levels of S1P and C1P have been seen to increase in the bone marrow microenvironment; moreover, peripheral circulating HSPCs are exposed to relatively high levels of $\mathrm{S} 1 \mathrm{P}$ and C1P present in the circulation. Both these mechanisms may desensitize responses to potential homing gradients of these bioactive lipids [129].

\section{ATP and UTP}

5-nucleotide triphosphates, particularly ATP and UTP, engage P2 nucleotide receptor-mediated regulation of proliferation, differentiation, cell death, and chemotaxis on hematopoietic cells including HSPCs. UTP is thought to represent an endogenous danger signal, which is rapidly released into the extracellular environment due to tissue injury and cell death. UTP and other nucleotides induce migration of leukocytes into the injured tissue, stimulate tissue recovery by induction of cell proliferation, and promote resolution of the immune response by activating anti-inflammatory pathways $[140,141]$. Preincubation of HSPCs with UTP significantly improved CXCR4-induced migration of HSPCs in vitro, whereas UTP itself only induces marginal chemotactic migration of HSPCs [130]. In addition, pre-treatment with UTP alone or in combination with CXCL12/SDF-1 significantly increases cell adhesion to fibronectin and UTP pre-treatment improves homing of human HSPCs to the bone marrow [130, 142]. Involvement of UTP signaling in PBSC mobilization remains to be elucidated. Inhibition of CXCL12- and UTP-dependent chemotaxis by pertussis toxin suggests that Rho guanosine $5^{\prime}$-triphosphatase (GTPase) Rac2 and its effectors Rho GTPase-activated kinases 1 and 2 (ROCK1/2) are involved in UTP-regulated/CXCL12-dependent HSPC migration [130].

\section{Uridine Diphosphate-Glucose}

Uridine diphosphate-glucose (UDP-glc) is released into extracellular fluids in response to stress. UDP-glc has been shown to mobilize long-term repopulating HSPCs, and co-administration of UDP-glc and G-CSF led to greater HSPC mobilization than G-CSF alone [143]. In competitive repopulation experiments, HSPCs mobilized with UDP-glc plus G-CSF repopulated better than HSPCs mobilized with G-CSF alone. In comparison with G-CSF, UDPglc-mobilized HSPCs exhibited a more lymphoid-biased differentiation capacity, indicating that UDP-glc mobilizes a functionally distinct subset of HSPCs [143]. In contrast, inhibition experiments showed that reactive oxygen species (ROS) are mediators of UDPglc-mediated HSPC mobilization. Application of the ROS inhibitor $\mathrm{N}$-acetyl-L-cysteine (NAC) was able to significantly abrogate UDPglc-induced HSPC mobilization. Kook et al. suggest that ROS induce enhancement in receptor activator of nuclear factor kappa-B ligand (RANKL) expression and a RANKL-induced osteoclast differentiation, leading to HSPC mobilization [143].

\section{$\mathrm{Ca}^{2+}$ and the $\mathrm{CaR}$}

HSPCs express the seven-transmembrane-spanning CaR which is strongly involved in retention and liberation of HSPCs in/from the stem cell niche. Newborn mice deficient in CaR revealed a reduced cellularity in the bone marrow and a lack of primitive HSPCs, whereas increased numbers of HSPCs were found in the circulation and spleen. The fetal liver of CaR-/- mice had normal numbers of HSPCs with normal proliferation, differentiation, and migrational capacity. But these HSPCs revealed an adhesion defect to collagen I, leading to a defective lodgment to the endosteal niche [144]. On the other hand, pharmacological activation of $\mathrm{CaR}$ with cinacalcet, a positive allosteric modulator of $\mathrm{CaR}$, resulted in increased adhesion of HSPCs to collagen I and fibronectin, an increased in vitro migration towards CXCL12/SDF-1and an increased in vivo homing and lodgment to the endosteal niche [145]. Wu et al. [146] showed that $\mathrm{Ca}^{2+}$ treatment increased transcription and expression of CXCR4 of bone marrow cells and SDF-1-mediated CXCR4 internalization. $\mathrm{Ca}^{2+}$ influx inhibitors or blocking of $\mathrm{CaR}$ inhibited $\mathrm{Ca}^{2+}$-induced CXCR4 expression, indicating that $\mathrm{Ca}^{2+}$-induced changes on HSPCs are partially modulated by an increased expression of CXCR4.

\section{Molecules, which Promote Incorporation of CXCR4 into}

Membrane Lipid Rafts

Cationic antimicrobial peptides (CAMPs), Cathelicidin LL-37, $\beta 2$-defensin, andC3a $[123,147]$ were found to highly improve responsiveness of HSPCs to picomolar levels of SDF-1/CXCL12 (1-2 $\mathrm{ng} / \mathrm{ml}$ ), which reflect the physiological SDF-1/CXCL12 concentrations in tissues, supporting the biological significance of this class of molecules in HSPCs $[148,149]$. These molecules improve incorporation of the CXCR4 receptor into membrane lipid rafts [123, 147]. Within membrane lipid rafts, several cellular signaling molecules are assembled, such as small guanine nucleotide triphosphatases (GTPases) Rac-1 and Rac-2, known to be important for the lodgment of HSPCs into niches or, when blocked, for mobilization [150-152]. Co-localization of CXCR4 and Rac-1 in lipid rafts may improve GTP binding and activation of Rac-1 [153-156].

Cathelicidin LL-37 is an antimicrobial peptide expressed by bone marrow stromal cells and is upregulated after bone marrow irradiation. It was shown that LL-37 enhances chemotactic migration and adhesiveness of HSPCs and that short-time pre-incubation of HSPCs with LL-37 prior to transplantation accelerates recovery of platelet and neutrophil counts in mice [148]. Its effect on mobilization remains to be determined.

\section{Prostaglandin E2}

Murine and human HSPCs express prostaglandin E2 (PGE2) receptors. In murine transplantation experiments, short-term ex vivo exposure to PGE2 enhances homing and proliferation of HSPCs and increases the number of primitive, long-term repopulating cells, indicating that PGE2 supports self-renewal of HSPCs $[157,158]$. In contrast, differentiation of immature myeloid progenitor cells leading to colony-forming units-granulocyte macrophage (CFU-GM) and macrophage (CFU-M) is suppressed by 
PGE2 [159-161], suggesting a differential regulation of the hematopoiesis by PGE2. Blocking of PGE2 production by nonsteroidal anti-inflammatory drugs (NSAID) such as indomethacin, aspirin, ibuprofen, and meloxicam doubled G-CSF-induced HSPC mobilization. Transplantation of G-CSF + NSAID-mobilized grafts was associated with a faster regeneration of posttransplant hematopoiesis [162]. The significance of PEG2 in the bone marrow niche is supported by the findings of i) an increased PGE2 production by irradiated bone marrow stromal cells, and ii) a C1P- and S1P-induced, increased expression of cyclooxygenase 2 in stromal cells, whereby $\mathrm{C} 1 \mathrm{P}$ and $\mathrm{S} 1 \mathrm{P}$ is released from lethally irradiated, damaged bone marrow cells, suggesting that conditioning for HSPC transplantation by lethal irradiation induces PGE2 production in bone marrow [118].

PGE2 treatment increases cellular CXCR4 mRNA concentration and the expression of CXCR4 on the HSPC surface, leading to an enhanced migration to SDF-1/CXCL12 in vitro and homing to bone marrow in vivo. Furthermore, PGE2 enhances HSPC survival due to an increased expression of survivin and reduction in intracellular active caspase-3 [157]. Another mechanism, which is important for PGE2-mediated modulation of HSPC retention and egress of HSPCs into the blood, is the regulation of osteopontin expression. Hoggatt et al. [162] suggested that blockade of PGE2 synthesis by NSAID lead to a reduction in osteopontin expression, which is responsible for the retention of HSPCs in the stem cell niche. Also, osteopontin is a negative regulator of the size of the stem cell pool, and down-regulation or absence of osteopontin is associated with an increased number of primitive HSPCs [21]. Thus, osteopontin expressed by stromal cells may be associated with a superior repopulating ability and long-term engraftment of G-CSF plus NSAID mobilized stem cell graft compared to grafts mobilized with G-CSF alone [162].

\section{EPI-X4, an Endogenous Human CXCR4 Antagonist}

EPI-X4 is a 16 amino acid peptide isolated from human blood filtrate and plasma and generated from albumin by aspartic proteases cathepsin D and $\mathrm{E}$ under acidic conditions [163]. These proteases are released from immune cells during inflammatory processes $[164,165]$. Neutrophils were shown to produce EPI-X4 from albumin [163]. Since neutrophilic granulocytes in the bone marrow are strongly activated during HSPC mobilization with G-CSF, which leads to a highly proteolytic environment $[72,166]$, and since albumin is distributed throughout the extracellular space of the bone marrow [167], regulation of the CXCR4-SDF-1/CXCL12 axis by EPI-X4 production in the bone marrow is a possibility, which is in line with the idea that single intraperitoneal injection of EPI-X4 into mice resulted in marked mobilization of HSPCs, which engrafted lethally irradiated hosts [163].

\section{Open Questions in the Field}

Until now, a plethora of intelligent studies have been conducted to better understand the nature of niches in the bone marrow and their interaction with HSPCs. Meanwhile, more than 20 individual signals have been identified which are active to hold HSPCs in the niche. On the other hand, research on HSPC mobilization has shown that many of the endpoints of the mobilization target molecules which are made responsible for niche localization of HSPCs. Figures 1 and 2B demonstrate some of these pathways. More cell types, signals, and molecules have been found, which seem to be involved in inducing HSPC mobilization. These include granulocytes, monocytic cells, proteases, chemokines, peptides, and endogenous CXCR4 inhibitor, a number of CXCL12 axis modulators, and other substances as nucleotides or sphingolipids.

To further clarify the interdependence of HSPC maintenance and niche localization, it would be valuable to learn about some more central questions.

Open questions and fields for new research include:

- The role of chemokine gradients in HSPC steady-state hematopoiesis

- The sources and the role of sphingolipids and nucelotides/nucleotide analogues in steady-state hematopoiesis and during mobilization

- The constituents and dynamics of bone marrow interstitial fluid, and how its soluble mediators are embedded in regulation of the HSPC niche maintenance and HSPC mobilization

- The role of neutrophilic granulocytes and their secreted proteases in steady-state hematopoiesis.

It needs to be clarified whether signals such as $\mathrm{CaR}$-mediated and $\beta$-adrenergic innervation are part of intrinsic feedback signaling loops, and which other players are involved in such possible circuits

The question remains whether the continuous exit of HSPCs into the bloodstream and their re-entry into bone marrow, as seen in steady state and during induced mobilization, are mediated by the same mechanism or are regulated differently.

\section{Disclosure Statement}

The authors declare no competing interests. 


\section{References}

1 Dexter TM, Allen TD, Lajtha LG, Schofield R, Lord BI: Stimulation of differentiation and proliferation of haemopoietic cells in vitro. J Cell Physiol 1973;82: 461-473.

2 Schofield R: The relationship between the spleen colony-forming cell and the haemopoietic stem cell. Blood Cells 1978;4:7-25.

3 Morrison SJ, Spradling AC: Stem cells and niches: mechanisms that promote stem cell maintenance throughout life. Cell 2008;132:598-611.

4 Boulais PE, Frenette PS: Making sense of hematopoietic stem cell niches. Blood 2015;125:2621-2629.

5 Siena S, Bregni M, Gianni AM: Mobilization of peripheral blood progenitor cells for autografting: chemotherapy and G-CSF or GM-CSF. Baillieres Best Pract Res Clin Haematol 1999;12:27-39.

6 Anasetti C, Logan BR, Lee SJ, Waller EK, Weisdorf DJ, Wingard JR, Cutler CS, Westervelt P, Woolfrey A, Couban S, Ehninger G, Johnston L, Maziarz RT, Pulsipher MA, Porter DL, Mineishi S, McCarty JM, Khan SP, Anderlini P, Bensinger WI, Leitman SF, Rowley SD, Bredeson C, Carter SL, Horowitz MM, Confer DL, Blood, Marrow Transplant Clinical Trials Network: Peripheral-blood stem cells versus bone marrow from unrelated donors. N Engl J Med 2012;367:1487-1496.

7 Schofield R, Lord BI, Humphreys ER, Stones VA: Effects of plutonium-239 on haemopoiesis. I. Quantitative and qualitative changes in CFU-S in different regions of the mouse femur and vertebrae. Int J Radiat Biol Relat Stud Phys Chem Med 1986;49:1021-1029.

8 Benayahu D, Horowitz M, Zipori D, Wientroub S: Hemopoietic functions of marrow-derived osteogenic cells. Calcif Tissue Int 1992;51:195-201.

9 Benayahu D, Kletter Y, Zipori D, Wientroub S: Bone marrow-derived stromal cell line expressing osteoblastic phenotype in vitro and osteogenic capacity in vivo. J Cell Physiol 1989;140:1-7.

10 Taichman R, Reilly M, Verma R, Ehrenman K, Emerson $\mathrm{S}$ : Hepatocyte growth factor is secreted by osteoblasts and cooperatively permits the survival of haematopoietic progenitors. Br J Haematol 2001;112:438-448.

11 Taichman RS, Reilly MJ, Emerson SG: Human osteoblasts support human hematopoietic progenitor cells in vitro bone marrow cultures. Blood 1996;87:518524.

12 Taichman RS, Emerson SG: Human osteoblasts support hematopoiesis through the production of granulocyte colony-stimulating factor. J Exp Med 1994;179: 1677-1682.

13 Nilsson SK, Johnston HM, Coverdale JA: Spatial localization of transplanted hemopoietic stem cells: inferences for the localization of stem cell niches. Blood 2001;97:2293-2299.

14 Zhang J, C. N, Ye L, Huang H, He X, Tong WG, Ross J, Haug J, Johnson T, Feng JQ, Harris S, Wiedemann LM, Mishina Y, Li L: Identification of the haematopoietic stem cell niche and control of the niche size. Nature 2003;425:836-841.

15 Calvi LM, G.B. A, Weibrecht KW, Weber JM, Olson DP, Knight MC, Martin RP, Schipani E, Divieti P, Bringhurst FR, Milner LA, Kronenberg HM, Scadden DT: Osteoblastic cells regulate the haematopoietic stem cell niche. Nature 2003;425:841-846.

16 Stier S, Cheng T, Dombkowski D, Carlesso N, Scadden DT: Notch1 activation increases hematopoietic stem cell self-renewal in vivo and favors lymphoid over myeloid lineage outcome. Blood 2002;99:2369-2378.

17 Karanu FN, Murdoch B, Gallacher L, Wu DM, Koremoto M, Sakano S, Bhatia M: The notch ligand jagged-1 represents a novel growth factor of human hematopoietic stem cells. J Exp Med 2000;192:13651372 .
18 Arai F, Hirao A, Ohmura M, Sato H, Matsuoka S, Takubo K, Ito K, Koh GY, Suda T: Tie2/angiopoietin-1 signaling regulates hematopoietic stem cell quiescence in the bone marrow niche. Cell 2004;118:149-161.

19 Qian H, Buza-Vidas N, Hyland CD, Jensen CT, Antonchuk J, Mansson R, Thoren LA, Ekblom M, Alexander WS, Jacobsen SE: Critical role of thrombopoietin in maintaining adult quiescent hematopoietic stem cells. Cell Stem Cell 2007;1:671-684.

20 Yoshihara H, Arai F, Hosokawa K, Hagiwara T, Takubo K, Nakamura Y, Gomei Y, Iwasaki H, Matsuoka S, Miyamoto K, Miyazaki H, Takahashi T, Suda T: Thrombopoietin/MPL signaling regulates hematopoietic stem cell quiescence and interaction with the osteoblastic niche. Cell Stem Cell 2007;1:685-697.

21 Stier S, Ko Y, Forkert R, Lutz C, Neuhaus T, Grunewald E, Cheng T, Dombkowski D, Calvi LM, Rittling SR, Scadden DT: Osteopontin is a hematopoietic stem cell niche component that negatively regulates stem cell pool size. J Exp Med 2005;201:1781-1791.

22 Iwata M, Awaya N, Graf L, Kahl C, Torok-Storb B: Human marrow stromal cells activate monocytes to secrete osteopontin, which down-regulates Notch1 gene expression in CD34+ cells. Blood 2004;103:4496-4502.

23 Lo Celso C, Fleming HE, Wu JW, Zhao CX, Miake-Lye S, Fujisaki J, Cote D, Rowe DW, Lin CP, Scadden DT: Live-animal tracking of individual haematopoietic stem/progenitor cells in their niche. Nature 2009;457: 92-96.

24 Adams GB, Chabner KT, Alley IR, Olson DP, Szczepiorkowski ZM, Poznansky MC, Kos CH, Pollak MR, Brown EM, Scadden DT: Stem cell engraftment at the endosteal niche is specified by the calcium-sensing receptor. Nature 2006;439:599-603.

25 Scott MK, Akinduro O, Lo Celso C: In vivo 4-dimensional tracking of hematopoietic stem and progenitor cells in adult mouse calvarial bone marrow. J Vis Exp 2014:e51683

26 Xie Y, Yin T, Wiegraebe W, He XC, Miller D, Stark D, Perko K, Alexander R, Schwartz J, Grindley JC, Park J, Haug JS, Wunderlich JP, Li H, Zhang S, Johnson T, Feldman RA, Li L: Detection of functional haematopoietic stem cell niche using real-time imaging. Nature 2009;457:97-101.

27 Lichtman MA: The ultrastructure of the hemopoietic environment of the marrow: a review. Exp Hematol 1981;9:391-410.

28 Friedenstein AJ, Chailakhjan RK, Lalykina KS: The development of fibroblast colonies in monolayer cultures of guinea-pig bone marrow and spleen cells. Cell Tissue Kinet 1970;3:393-403.

29 Simmons PJ, Torok-Storb B: Identification of stromal cell precursors in human bone marrow by a novel monoclonal antibody, STRO-1. Blood 1991;78:55-62.

30 Simmons PJ, Gronthos S, Zannettino A, Ohta S, Graves S: Isolation, characterization and functional activity of human marrow stromal progenitors in hemopoiesis. Prog Clin Biol Res 1994;389:271-280.

31 Haynesworth SE, Baber MA, Caplan AI: Cell surface antigens on human marrow-derived mesenchymal cells are detected by monoclonal antibodies. Bone 1992;13:69-80

32 Sacchetti B, Funari A, Michienzi S, Di Cesare S, Piersanti S, Saggio I, Tagliafico E, Ferrari S, Robey PG, Riminucci M, Bianco P: Self-renewing osteoprogenitors in bone marrow sinusoids can organize a hematopoietic microenvironment. Cell 2007;131:324-336.

33 Mendez-Ferrer S, Michurina TV, Ferraro F, Mazloom AR, Macarthur BD, Lira SA, Scadden DT, Ma'ayan A, Enikolopov GN, Frenette PS: Mesenchymal and haematopoietic stem cells form a unique bone marrow niche. Nature 2010;466:829-834.
34 Pinho S, Lacombe J, Hanoun M, Mizoguchi T, Bruns I Kunisaki Y, Frenette PS: PDGFRalpha and CD51 mark human nestin+ sphere-forming mesenchymal stem cells capable of hematopoietic progenitor cell expansion. J Exp Med 2013;210:1351-1367.

35 Kiel MJ, Yilmaz OH, Iwashita T, Yilmaz OH, Terhorst C, Morrison SJ: SLAM family receptors distinguish hematopoietic stem and progenitor cells and reveal endothelial niches for stem cells. Cell 2005;121:1109-1121.

36 Peled A, Petit I, Kollet O, Magid M, Ponomaryov T, Byk T, Nagler A, Ben-Hur H, Many A, Shultz L, Lider O, Alon R, Zipori D, Lapidot T: Dependence of human stem cell engraftment and repopulation of NOD/SCID mice on CXCR4. Science 1999;283:845-848.

37 Sugiyama T, Kohara H, Noda M, Nagasawa T: Maintenance of the hematopoietic stem cell pool by CXCL12CXCR4 chemokine signaling in bone marrow stromal cell niches. Immunity 2006;25:977-988.

38 Nagasawa T: New niches for B cells. Nat Immuno 2008;9:345-346.

39 Sugiyama T, Kohara H, Noda M, Nagasawa T: Maintenance of the hematopoietic stem cell pool by CXCL12 CXCR4 chemokine signaling in bone marrow stroma cell niches. Immunity 2006;25:977-988.

40 Mendez-Ferrer S, Battista M, Frenette PS: Cooperation of beta(2)- and beta(3)-adrenergic receptors in hematopoietic progenitor cell mobilization. Ann N Y Acad Sci 2010;1192:139-144.

41 Adams GB, Martin RP, Alley IR, Chabner KT, Cohen KS, Calvi LM, Kronenberg HM, Scadden DT: Therapeutic targeting of a stem cell niche. Nat Biotechnol 2007;25:238-243.

42 Katayama Y, Battista M, Kao WM, Hidalgo A, Peired AJ, Thomas SA, Frenette PS: Signals from the sympathetic nervous system regulate hematopoietic stem cel egress from bone marrow. Cell 2006;124:407-421.

43 Mendez-Ferrer S, Lucas D, Battista M, Frenette PS: Haematopoietic stem cell release is regulated by circadian oscillations. Nature 2008;452:442-447.

44 Yamazaki S, Ema H, Karlsson G, Yamaguchi T Miyoshi H, Shioda S, Taketo MM, Karlsson S, Iwama A, Nakauchi H: Nonmyelinating Schwann cells maintain hematopoietic stem cell hibernation in the bone marrow niche. Cell 2011;147:1146-1158.

45 Omatsu Y, Sugiyama T, Kohara H, Kondoh G, Fujii N, Kohno K, Nagasawa T: The essential functions of adipo-osteogenic progenitors as the hematopoietic stem and progenitor cell niche. Immunity 2010;33:387-399.

46 Kunisaki Y, Bruns I, Scheiermann C, Ahmed J, Pinho S, Zhang D, Mizoguchi T, Wei Q, Lucas D, Ito K, Mar JC, Bergman A, Frenette PS: Arteriolar niches maintain haematopoietic stem cell quiescence. Nature 2013; 502:637-643.

$47 \mathrm{Hu}$ X, Garcia M, Weng L, Jung X, Murakami JL, Kumar B, Warden CD, Todorov I, Chen CC: Identification of a common mesenchymal stromal progenitor for the adult haematopoietic niche. Nat Commun 2016;7:13095.

48 Kobayashi H, Butler JM, O’Donnell R, Kobayashi M, Ding BS, Bonner B, Chiu VK, Nolan DJ, Shido K, Benjamin L, Rafii S: Angiocrine factors from Akt-activated endothelial cells balance self-renewal and differentiation of haematopoietic stem cells. Nat Cell Biol 2010; 12:1046-1056.

49 Hooper AT, Butler JM, Nolan DJ, Kranz A, Iida K, Kobayashi M, Kopp HG, Shido K, Petit I, Yanger K, James D, Witte L, Zhu Z, Wu Y, Pytowski B, Rosenwaks Z, Mittal V, Sato TN, Rafii S: Engraftment and reconstitution of hematopoiesis is dependent on VEGFR2-mediated regeneration of sinusoidal endothelial cells. Cell Stem Cell 2009;4:263-274. 
50 Tian DM, Liang YM, Zhang YQ: Endothelium-targeted human delta-like 1 enhances the regeneration and homing of human cord blood stem and progenitor cells. J Transl Med 2016;14:5.

51 Butler JM, Nolan DJ, Vertes EL, Varnum-Finney B, Kobayashi H, Hooper AT, Seandel M, Shido K, White IA, Kobayashi M, Witte L, May C, Shawber C, Kimura Y, Kitajewski J, Rosenwaks Z, Bernstein ID, Rafii S: Endothelial cells are essential for the self-renewal and repopulation of Notch-dependent hematopoietic stem cells. Cell Stem Cell 2010;6:251-264.

52 Poulos MG, Guo P, Kofler NM, Pinho S, Gutkin MC Tikhonova A, Aifantis I, Frenette PS, Kitajewski J, Rafii S, Butler JM: Endothelial Jagged-1 is necessary for homeostatic and regenerative hematopoiesis. Cell Rep 2013;4:1022-1034

53 Himburg HA, Harris JR, Ito T, Daher P, Russell JL, Quarmyne M, Doan PL, Helms K, Nakamura M, Fixsen E, Herradon G, Reya T, Chao NJ, Harroch S, Chute JP: Pleiotrophin regulates the retention and self-renewal of hematopoietic stem cells in the bone marrow vascular niche. Cell Rep 2012;2:964-975.

54 Ding L, Morrison SJ: Haematopoietic stem cells and early lymphoid progenitors occupy distinct bone marrow niches. Nature 2013;495:231-235.

55 Ding L, Saunders TL, Enikolopov G, Morrison SJ Endothelial and perivascular cells maintain haematopoietic stem cells. Nature 2012;481:457-462.

56 Acar M, Kocherlakota KS, Murphy MM, Peyer JG, Oguro H, Inra CN, Jaiyeola C, Zhao Z, Luby-Phelps K, Morrison SJ: Deep imaging of bone marrow shows non-dividing stem cells are mainly perisinusoidal. Nature 2015;526:126-130.

57 Winkler IG, Barbier V, Nowlan B, Jacobsen RN, Forristal CE, Patton JT, Magnani JL, Levesque JP: Vascular niche E-selectin regulates hematopoietic stem cell dormancy, self renewal and chemoresistance. Nat Med 2012;18:1651-1657.

58 Chen S, Li H, Li S, Yu J, Wang M, Xing H, Tang K, Tian Z, Rao Q, Wang J: Racl GTPase promotes interaction of hematopoietic stem/progenitor cell with niche and participates in leukemia initiation and maintenance in mouse. Stem Cells 2016;34:1730-1741.

59 Chow A, Lucas D, Hidalgo A, Mendez-Ferrer S, Hashimoto D, Scheiermann C, Battista M, Leboeuf M Prophete C, van Rooijen N, Tanaka M, Merad M, Frenette PS: Bone marrow CD169+ macrophages promote the retention of hematopoietic stem and progenitor cells in the mesenchymal stem cell niche. J Exp Med 2011;208:261-271.

60 Christopher MJ, Rao M, Liu F, Woloszynek JR, Link DC: Expression of the G-CSF receptor in monocytic cells is sufficient to mediate hematopoietic progenitor mobilization by G-CSF in mice. J Exp Med 2011;208: 251-260.

61 Winkler IG, Sims NA, Pettit AR, Barbier V, Nowlan B, Helwani F, Poulton IJ, van Rooijen N, Alexander KA, Raggatt LJ, Levesque JP: Bone marrow macrophages maintain hematopoietic stem cell (HSPC) niches and their depletion mobilizes HSCs. Blood 2010;116:48154828.

62 Nakamura-Ishizu A, Takubo K, Fujioka M, Suda T: Megakaryocytes are essential for HSC quiescence through the production of thrombopoietin. Biochem Biophys Res Commun 2014;454:353-357.

63 Bruns I, Lucas D, Pinho S, Ahmed J, Lambert MP, Kunisaki Y, Scheiermann C, Schiff L, Poncz M, Bergman A, Frenette PS: Megakaryocytes regulate hematopoietic stem cell quiescence through CXCL4 secretion. Nat Med 2014;20:1315-1320.

64 Zhao M, Perry JM, Marshall H, Venkatraman A, Qian P, He XC, Ahamed J, Li L: Megakaryocytes maintain homeostatic quiescence and promote post-injury regeneration of hematopoietic stem cells. Nat Med 2014; 20:1321-1326.
65 Kovtonyuk LV, Fritsch K, Feng X, Manz MG, Takizawa $\mathrm{H}$ : Inflamm-aging of hematopoiesis, hematopoietic stem cells, and the bone marrow microenvironment. Front Immunol 2016;7:502.

66 Latchney SE, Calvi LM: The aging hematopoietic stem cell niche: phenotypic and functional changes and mechanisms that contribute to hematopoietic aging. Semin Hematol 2017;54:25-32.

67 Colmone A, Amorim M, Pontier AL, Wang S, Jablonski E, Sipkins DA: Leukemic cells create bone marrow niches that disrupt the behavior of normal hematopoietic progenitor cells. Science 2008;322:1861-1865.

68 Bonig H, Priestley GV, Oehler V, Papayannopoulou T: Hematopoietic progenitor cells (HPC) from mobilized peripheral blood display enhanced migration and marrow homing compared to steady-state bone marrow HPC. Exp Hematol 2007;35:326-334.

69 Greenbaum AM, Link DC: Mechanisms of G-CSFmediated hematopoietic stem and progenitor mobilization. Leukemia 2011;25:211-217.

70 Vermeulen M, F. LP, Gagnerault MC, Mary JY, Sainteny F, Lepault F: Role of adhesion molecules in the homing and mobilization of murine hematopoietic stem and progenitor cells. Blood 1998;92:894-900.

71 van der Loo JC, Xiao X, McMillin D, Hashino K, Kato I, Williams DA: VLA-5 is expressed by mouse and human long-term repopulating hematopoietic cells and mediates adhesion to extracellular matrix protein fibronectin. J Clin Invest 1998;102:1051-1061.

72 Levesque JP, Hendy J, Takamatsu Y, Williams B, Winkler IG, Simmons PJ: Mobilization by either cyclophosphamide or granulocyte colony-stimulating factor transforms the bone marrow into a highly proteolytic environment. Exp Hematol 2002;30:440-449.

73 Levesque JP, Hendy J, Winkler IG, Takamatsu Y, Simmons PJ: Granulocyte colony-stimulating factor induces the release in the bone marrow of proteases that cleave c-KIT receptor (CD117) from the surface of hematopoietic progenitor cells. Exp Hematol 2003;31:109-117.

74 Valenzuela-Fernandez A, Planchenault T, Baleux F, Staropoli I, Le-Barillec K, Leduc D, Delaunay T, Lazarini F, Virelizier JL, Chignard M, Pidard D, Arenzana-Seisdedos F: Leukocyte elastase negatively regulates stromal cell-derived factor-1 (SDF-1)/ CXCR4 binding and functions by amino-terminal processing of SDF-1 and CXCR4. J Biol Chem 2002;277: 15677-15689.

75 Heissig B, Hattori K, Dias S, Friedrich M, Ferris B, Hackett NR, Crystal RG, Besmer P, Lyden D, Moore MA, Werb Z, Rafii S: Recruitment of stem and progenitor cells from the bone marrow niche requires MMP-9 mediated release of kit-ligand. Cell 2002;109: 625-637.

76 Karpova D, Wiercinska E, Bönig H: Mobilization of hematopoietic stem/progenitor cells. Transfusionsmedizin 2013;3:127-139

77 Dar A, Schajnovitz A, Lapid K, Kalinkovich A, Itkin T, Ludin A, Kao WM, Battista M, Tesio M, Kollet O, Cohen NN, Margalit R, Buss EC, Baleux F, Oishi S, Fujii N, Larochelle A, Dunbar CE, Broxmeyer HE, Frenette PS, Lapidot T: Rapid mobilization of hematopoietic progenitors by AMD3100 and catecholamines is mediated by CXCR4-dependent SDF-1 release from bone marrow stromal cells. Leukemia 2011;25:1286-1296.

78 Ara T, Tokoyoda K, Sugiyama T, Egawa T, Kawabata K, Nagasawa T: Long-term hematopoietic stem cells require stromal cell-derived factor-1 for colonizing bone marrow during ontogeny. Immunity 2003;19: 257-267.

79 Tzeng YS, Li H, Kang YL, Chen WC, Cheng WC, Lai DM: Loss of Cxcl12/Sdf-1 in adult mice decreases the quiescent state of hematopoietic stem/progenitor cells and alters the pattern of hematopoietic regeneration after myelosuppression. Blood 2011;117:429-439.
80 Nie Y, Han YC, Zou YR: CXCR4 is required for the quiescence of primitive hematopoietic cells. J Exp Med 2008;205:777-783.

81 Peled A, Grabovsky V, Habler L, Sandbank J, Arenzana-Seisdedos F, Petit I, Ben-Hur H, Lapidot T, Alon R: The chemokine SDF-1 stimulates integrin-mediated arrest of CD34 $(+)$ cells on vascular endothelium under shear flow. J Clin Invest 1999;104:1199-1211.

82 Peled A, Kollet O, Ponomaryov T, Petit I, Franitza S Grabovsky V, Slav MM, Nagler A, Lider O, Alon R, Zipori $\mathrm{D}$, Lapidot $\mathrm{T}$ : The chemokine SDF-1 activates the integrins LFA-1, VLA-4, and VLA- 5 on immature human CD34(+) cells: role in transendothelial/stromal migration and engraftment of NOD/SCID mice. Blood 2000;95:3289-3296.

83 Avigdor A, Goichberg P, Shivtiel S, Dar A, Peled A, Samira S, Kollet O, Hershkoviz R, Alon R, Hardan I, Ben-Hur H, Naor D, Nagler A, Lapidot T: CD44 and hyaluronic acid cooperate with SDF-1 in the trafficking of human CD34+ stem/progenitor cells to bone marrow. Blood 2004;103:2981-2989.

84 Tesio M, Golan K, Corso S, Giordano S, Schajnovitz A, Vagima Y, Shivtiel S, Kalinkovich A, Caione L, Gammaitoni L, Laurenti E, Buss EC, Shezen E, Itkin T, Kollet O, Petit I, Trumpp A, Christensen J, Aglietta M, Piacibello W, Lapidot T: Enhanced c-Met activity promotes G-CSF-induced mobilization of hematopoietic progenitor cells via ROS signaling. Blood 2011;117: 419-428.

85 Petit I, Szyper-Kravitz M, Nagler A, Lahav M, Peled A, Habler L, Ponomaryov T, Taichman RS, ArenzanaSeisdedos F, Fujii N, Sandbank J, Zipori D, Lapidot T: G-CSF induces stem cell mobilization by decreasing bone marrow SDF-1 and up-regulating CXCR4. Nat Immunol 2002;3:687-694.

86 Lapid K, Glait-Santar C, Gur-Cohen S, Canaani J, Kollet O, Lapidot T: Egress and Mobilization of Hematopoietic Stem and Progenitor Cells: A Dynamic MultiFacet Process; in StemBook, Cambridge, Harvard Stem Cell Institute, 2012. www.ncbi.nlm.nih.gov/books/ NBK133261/ (last accessed May 8, 2017).

87 Christopher MJ, Liu F, Hilton MJ, Long F, Link DC: Suppression of CXCL12 production by bone marrow osteoblasts is a common and critical pathway for cytokine-induced mobilization. Blood 2009;114:13311339.

88 Fukuda S, Bian H, King AG, Pelus LM: The chemokine GRObeta mobilizes early hematopoietic stem cells characterized by enhanced homing and engraftment. Blood 2007;110:860-869.

89 van Pel M, van Os R, Velders GA, Hagoort $H$, Heegaard PM, Lindley IJ, Willemze R, Fibbe WE: Serpinal is a potent inhibitor of IL-8-induced hematopoietic stem cell mobilization. Proc Natl Acad Sci U S A 2006; 103:1469-1474.

90 Ryan MA, Nattamai KJ, Xing E, Schleimer D, Daria D, Sengupta A, Kohler A, Liu W, Gunzer M, Jansen M, Ratner N, Le Cras TD, Waterstrat A, Van Zant G, Cancelas JA, Zheng Y, Geiger H: Pharmacological inhibition of EGFR signaling enhances G-CSF-induced hematopoietic stem cell mobilization. Nat Med 2010; 16:1141-1146.

91 Pitchford SC, Furze RC, Jones CP, Wengner AM, Rankin SM: Differential mobilization of subsets of progenitor cells from the bone marrow. Cell Stem Cell 2009;4:62-72.

92 Sugiyama A, Yujiri T, Tanaka M, Tanaka Y, Nakamura Y, Tanizawa Y: Altered expression of circadian clock genes during peripheral blood stem cell mobilization induced by granulocyte colony-stimulating factor. Chronobiol Int 2015;32:934-941. 
93 Broxmeyer HE, Orschell CM, Clapp DW, Hangoc G, Cooper S, Plett PA, Liles WC, Li X, Graham-Evans B, Campbell TB, Calandra G, Bridger G, Dale DC, Srour EF: Rapid mobilization of murine and human hematopoietic stem and progenitor cells with AMD3100, a CXCR4 antagonist. J Exp Med 2005;201:1307-1318.

94 Worel N, Apperley JF, Basak GW, Douglas KW, Gabriel IH, Geraldes C, Hubel K, Jaksic O, Koristek Z, Lanza F, Lemoli R, Mikala G, Selleslag D, Duarte RF, Mohty M: European data on stem cell mobilization with plerixafor in patients with nonhematologic diseases: an analysis of the European Consortium of Stem Cell Mobilization. Transfusion 2012;52:2395-2400.

95 Bilgin YM, de Greef GE: Plerixafor for stem cell mobilization: the current status. Curr Opin Hematol 2016; 23:67-71.

96 Abraham M, Biyder K, Begin M, Wald H, Weiss ID, Galun E, Nagler A, Peled A: Enhanced unique pattern of hematopoietic cell mobilization induced by the CXCR4 antagonist 4F-benzoyl-TN14003. Stem Cells 2007;25:2158-2166.

97 Domingues MJ, Nilsson SK, Cao B: New agents in HSC mobilization. Int J Hematol 2017; 105: 141-152.

98 Kim AG, Vrecenak JD, Boelig MM, Eissenberg L, Rettig MP, Riley JS, Holt MS, Conner MA, Loukogeorgakis SP, Li H, DiPersio JF, Flake AW, Peranteau WH Enhanced in utero allogeneic engraftment in mice after mobilizing fetal HSCs by alpha4beta1/7 inhibition. Blood 2016;128:2457-2461.

99 Rosario M, Wyant T, Leach T, Sankoh S, Scholz C, Parikh A, Fox I, Feagan BG: Vedolizumab pharmacokinetics, pharmacodynamics, safety, and tolerability following administration of a single, ascending, intravenous dose to healthy volunteers. Clin Drug Investig 2016;36:913-923.

100 Golan K, Vagima Y, Ludin A, Itkin T, Cohen-Gur S, Kalinkovich A, Kollet O, Kim C, Schajnovitz A, Ovadya Y, Lapid K, Shivtiel S, Morris AJ, Ratajczak MZ, Lapidot T: S1P promotes murine progenitor cell egress and mobilization via S1P1-mediated ROS signaling and SDF-1 release. Blood 2012;119:2478-2488.

101 Cao B, Zhang Z, Grassinger J, Williams B, Heazlewood CK, Churches QI, James SA, Li S, Papayannopoulou T, Nilsson SK: Therapeutic targeting and rapid mobilization of endosteal HSC using a small molecule integrin antagonist. Nat Commun 2016;7:11007.

102 Gao Y, Dickerson JB, Guo F, Zheng J, Zheng Y: Rational design and characterization of a Rac GTPasespecific small molecule inhibitor. Proc Natl Acad Sci U S A 2004;101:7618-7623.

103 Cancelas JA, Lee AW, Prabhakar R, Stringer KF, Zheng Y, Williams DA: Rac GTPases differentially in tegrate signals regulating hematopoietic stem cell localization. Nat Med 2005;11:886-891.

104 Zoughlami Y, Voermans C, Brussen K, van Dort KA, Kootstra NA, Maussang D, Smit MJ, Hordijk PL, van Hennik PB: Regulation of CXCR4 conformation by the small GTPase Rac1:implications for HIV infection. Blood 2012;119:2024-2032.

105 Ferraro F, Lymperi S, Mendez-Ferrer S, Saez B, Spencer JA, Yeap BY, Masselli E, Graiani G, Prezioso L, Rizzini EL, Mangoni M, Rizzoli V, Sykes SM, Lin CP, Frenette PS, Quaini F, Scadden DT: Diabetes impairs hematopoietic stem cell mobilization by altering niche function. Sci Transl Med 2011;3:104ra101.

106 Richter R, Jochheim-Richter A, Ciuculescu F, Kollar K, Seifried E, Forssmann U, Verzijl D, Smit MJ, Blanchet $\mathrm{X}$, von Hundelshausen P, Weber C, Forssmann WG Henschler R: Identification and characterization of circulating variants of CXCL12 from human plasma: effects on chemotaxis and mobilization of hematopoietic stem and progenitor cells. Stem Cells Dev 2014;23: 1959-1974.
107 Dao MA, Creer MH, Nolta JA, Verfaillie CM: Biology of umbilical cord blood progenitors in bone marrow niches. Blood 2007;110:74-81.

108 Ding L, Morrison SJ: Haematopoietic stem cells and early lymphoid progenitors occupy distinct bone marrow niches. Nature 2013;495:231-235.

109 Greenbaum A, Hsu YM, Day RB, Schuettpelz LG, Christopher MJ, Borgerding JN, Nagasawa T, Link DC: CXCL12 in early mesenchymal progenitors is required for haematopoietic stem-cell maintenance. Nature 2013;495:227-230.

110 Tay J, Levesque JP, Winkler IG: Cellular players of hematopoietic stem cell mobilization in the bone marrow niche. Int J Hematol 2017;105:129-140.

111 Asada N, Katayama Y, Sato M, Minagawa K, Wakahashi K, Kawano H, Kawano Y, Sada A, Ikeda K, Matsui T, Tanimoto M: Matrix-embedded osteocytes regulate mobilization of hematopoietic stem/progenitor cells. Cell Stem Cell 2013;12:737-747.

112 Boettcher S, Gerosa RC, Radpour R, Bauer J, Ampenberger F, Heikenwalder M, Kopf M, Manz MG: Endothelial cells translate pathogen signals into G-CSFdriven emergency granulopoiesis. Blood 2014;124: 1393-1403.

113 Kwak H, Salvucci O, Weigert R, Martinez-Torrecuadrada JL, Henkemeyer M, Poulos MG, Butler JM, Tosato G: Sinusoidal ephrin receptor EPHB4 controls hematopoietic progenitor cell mobilization from bone marrow. J Clin Invest 2016;126:4554-4568.

114 Lee HM, Wu W, Wysoczynski M, Liu R, Zuba-Surma EK, Kucia M, Ratajczak J, Ratajczak MZ: Impaired mobilization of hematopoietic stem/progenitor cells in C5-deficient mice supports the pivotal involvement of innate immunity in this process and reveals novel promobilization effects of granulocytes. Leukemia 2009; 23:2052-2062.

115 Szumilas P, Barcew K, Baśkiewicz-Masiuk M, Wiszniewska B, Ratajczak MZ, Machaliński B: Effect of stem cell mobilization with cyclophosphamide plus granulocyte colony-stimulating factor on morphology of haematopoietic organs in mice. Cell Prolif 2005;38: 47-61.

116 Day RB, Link DC: Regulation of neutrophil trafficking from the bone marrow. Cell Mol Life Sci 2012;69: 1415-1423.

117 Liu F, Poursine-Laurent J, Link DC: Expression of the G-CSF receptor on hematopoietic progenitor cells is not required for their mobilization by G-CSF. Blood 2000;95:3025-3031.

$118 \mathrm{Kim} \mathrm{CH}, \mathrm{Wu}$ W, Wysoczynski M, Abdel-Latif A, Sunkara M, Morris A, Kucia M, Ratajczak J, Ratajczak MZ: Conditioning for hematopoietic transplantation activates the complement cascade and induces a proteolytic environment in bone marrow: a novel role for bioactive lipids and soluble C5b-C9 as homing factors. Leukemia 2012;26:106-116.

119 Ratajczak MZ, Kim CH, Wojakowski W, JanowskaWieczorek A, Kucia M, Ratajczak J: Innate immunity as orchestrator of stem cell mobilization. Leukemia 2010;24:1667-1675.

120 Lambris JD, Ricklin D, Geisbrecht BV: Complement evasion by human pathogens. Nat Rev Microbiol 2008; 6:132-142.

121 Reca R, Mastellos D, Majka M, Marquez L, Ratajczak J, Franchini S, Glodek A, Honczarenko M, Spruce LA, Janowska-Wieczorek A, Lambris JD, Ratajczak MZ: Functional receptor for C3a anaphylatoxin is expressed by normal hematopoietic stem/progenitor cells, and C3a enhances their homing-related responses to SDF1. Blood 2003;101:3784-3793.
122 Ratajczak J, Reca R, Kucia M, Majka M, Allendorf DJ, Baran JT, Janowska-Wieczorek A, Wetsel RA, Ross GD, Ratajczak MZ: Mobilization studies in mice deficient in either $\mathrm{C} 3$ or $\mathrm{C} 3 \mathrm{a}$ receptor $(\mathrm{C} 3 \mathrm{aR})$ reveal a novel role for complement in retention of hematopoietic stem/progenitor cells in bone marrow. Blood 2004; 103:2071-2078.

123 Ratajczak MZ, Reca R, Wysoczynski M, Yan J, Ratajczak J: Modulation of the SDF-1-CXCR4 axis by the third complement component (C3) - implications for trafficking of CXCR4+ stem cells. Exp Hematol 2006; 34:986-995.

124 Adamiak M, Abdelbaset-Ismail A, Moore JBt, Zhao J, Abdel-Latif A, Wysoczynski M, Ratajczak MZ: Inducible nitric oxide synthase (iNOS) is a novel negative regulator of hematopoietic stem/progenitor cell trafficking. Stem Cell Rev 2017;13:92-103.

125 Seitz G, Boehmler AM, Kanz L, Mohle R: The role of sphingosine 1-phosphate receptors in the trafficking of hematopoietic progenitor cells. Ann N Y Acad Sci 2005; 1044:84-89.

126 Massberg S, von Andrian UH: Novel trafficking routes for hematopoietic stem and progenitor cells. Ann N Y Acad Sci 2009;1176:87-93.

127 Ratajczak MZ, Lee H, Wysoczynski M, Wan W, Marlicz W, Laughlin MJ, Kucia M, Janowska-Wieczorek A, Ratajczak J: Novel insight into stem cell mobilizationplasma sphingosine-1-phosphate is a major chemoattractant that directs the egress of hematopoietic stem progenitor cells from the bone marrow and its level in peripheral blood increases during mobilization due to activation of complement cascade/membrane attack complex. Leukemia 2010;24:976-985.

128 Juarez JG, Harun N, Thien M, Welschinger R, Baraz R, Pena AD, Pitson SM, Rettig M, DiPersio JF, Bradstock KF, Bendall LJ: Sphingosine-1-phosphate facilitates trafficking of hematopoietic stem cells and their mobilization by CXCR4 antagonists in mice. Blood 2012; 119:707-716.

129 Ratajczak MZ, Suszynska M, Borkowska S, Ratajczak J, Schneider G: The role of sphingosine-1 phosphate and ceramide-1 phosphate in trafficking of normal stem cells and cancer cells. Expert Opin Ther Targets 2014; 18:95-107.

130 Rossi L, Manfredini R, Bertolini F, Ferrari D, Fogli M, Zini R, Salati S, Salvestrini V, Gulinelli S, Adinolfi E, Ferrari S, Di Virgilio F, Baccarani M, Lemoli RM: The extracellular nucleotide UTP is a potent inducer of hematopoietic stem cell migration. Blood 2007;109:533542.

131 Adams GB, Chabner KT, Alley IR, Olson DP, Szczepiorkowski ZM, Poznansky MC, Kos CH, Pollak MR, Brown EM, Scadden DT: Stem cell engraftment at the endosteal niche is specified by the calcium-sensing receptor. Nature 2006;439:599-603.

132 Okajima F: Regulation of inflammation by extracellular acidification and proton-sensing GPCRs. Cell Signal 2013;25:2263-2271.

133 Pebay A, Bonder CS, Pitson SM: Stem cell regulation by lysophospholipids. Prostaglandins Other Lipid Mediat 2007;84:83-97.

134 Ito K, Anada Y, Tani M, Ikeda M, Sano T, Kihara A, Igarashi Y: Lack of sphingosine 1-phosphate-degrading enzymes in erythrocytes. Biochem Biophys Res Commun 2007;357:212-217

135 Liu J, Hsu A, Lee JF, Cramer DE, Lee MJ: To stay or to leave: Stem cells and progenitor cells navigating the S1P gradient. World J Biol Chem 2011;2:1-13.

136 Pappu R, Schwab SR, Cornelissen I, Pereira JP, Regard JB, Xu Y, Camerer E, Zheng YW, Huang Y, Cyster JG, Coughlin SR: Promotion of lymphocyte egress into blood and lymph by distinct sources of sphingosine1-phosphate. Science 2007;316:295-298. 
137 Sato K, Okajima F: Role of sphingosine 1-phosphate in anti-atherogenic actions of high-density lipoprotein. World J Biol Chem 2010;1:327-337.

138 Ryser MF, Ugarte F, Lehmann R, Bornhauser M, Brenner S: S1P(1) overexpression stimulates S1P-dependent chemotaxis of human CD34+ hematopoietic progenitor cells but strongly inhibits SDF-1/CXCR4-dependent migration and in vivo homing. Mol Immunol 2008;46:166-171.

139 Ogle ME, Olingy CE, Awojoodu AO, Das A, Ortiz RA, Cheung HY, Botchwey EA: Sphingosine-1-phosphate receptor-3 supports hematopoietic stem and progenitor cell residence within the bone marrow niche. Stem Cells 2017;35:1040-1052.

140 Di Virgilio F, Boeynaems JM, Robson SC: Extracellular nucleotides as negative modulators of immunity. Curr Opin Pharmacol 2009;9:507-513.

141 Blackburn MR, Vance CO, Morschl E, Wilson CN Adenosine receptors and inflammation. Handb Exp Pharmacol 2009:215-269.

142 Lemoli RM, Ferrari D, Fogli M, Rossi L, Pizzirani C, Forchap S, Chiozzi P, Vaselli D, Bertolini F, Foutz T, Aluigi M, Baccarani M, Di Virgilio F: Extracellular nucleotides are potent stimulators of human hematopoietic stem cells in vitro and in vivo. Blood 2004;104: 1662-1670.

143 Kook S, Cho J, Lee SB, Lee BC: The nucleotide sugar UDP-glucose mobilizes long-term repopulating primitive hematopoietic cells. J Clin Invest 2013;123:34203435.

144 Adams GB, Alley IR, Chung UI, Chabner KT, Jeanson NT, Lo Celso C, Marsters ES, Chen M, Weinstein LS, Lin CP, Kronenberg HM, Scadden DT: Haematopoietic stem cells depend on Galpha(s)-mediated signalling to engraft bone marrow. Nature 2009;459:103-107.

145 Lam BS, Cunningham C, Adams GB: Pharmacologic modulation of the calcium-sensing receptor enhances hematopoietic stem cell lodgment in the adult bone marrow. Blood 2011;117:1167-1175.

146 Wu Q, Shao H, Darwin ED, Li J, Li J, Yang B, Webster $\mathrm{KA}, \mathrm{Yu} \mathrm{H}$ : Extracellular calcium increases CXCR4 expression on bone marrow-derived cells and enhances pro-angiogenesis therapy. J Cell Mol Med 2009;13: 3764-3773.

147 Wysoczynski M, Reca R, Lee H, Wu W, Ratajczak J, Ratajczak MZ: Defective engraftment of C3aR-/- hematopoietic stem progenitor cells shows a novel role of the $\mathrm{C} 3 \mathrm{a}-\mathrm{C} 3 \mathrm{aR}$ axis in bone marrow homing. Leukemia 2009;23:1455-1461.
148 Wu W, Kim CH, Liu R, Kucia M, Marlicz W, Greco N, Ratajczak J, Laughlin MJ, Ratajczak MZ: The bone marrow-expressed antimicrobial cationic peptide LL-37 enhances the responsiveness of hematopoietic stem progenitor cells to an SDF-1 gradient and accelerates their engraftment after transplantation. Leukemia 2012;26:736-745.

149 Lehrer RI: Primate defensins. Nat Rev Microbiol 2004; 2:727-738.

$150 \mathrm{Gu}$ Y, Filippi MD, Cancelas JA, Siefring JE, Williams EP, Jasti AC, Harris CE, Lee AW, Prabhakar R, Atkinson SJ, Kwiatkowski DJ, Williams DA: Hematopoietic cell regulation by Rac1 and Rac2 guanosine triphosphatases. Science 2003;302:445-449.

151 Filippi MD, Harris CE, Meller J, Gu Y, Zheng Y, Williams DA: Localization of Rac2 via the $\mathrm{C}$ terminus and aspartic acid 150 specifies superoxide generation, actin polarity and chemotaxis in neutrophils. Nat Immunol 2004;5:744-751.

152 Cancelas JA, Lee AW, Prabhakar R, Stringer KF, Zheng Y, Williams DA: Rac GTPases differentially integrate signals regulating hematopoietic stem cell localization. Nat Med 2005;11:886-891.

$153 \mathrm{Gu}$ Y, Filippi MD, Cancelas JA, Siefring JE, Williams EP, Jasti AC, Harris CE, Lee AW, Prabhakar R, Atkinson SJ, Kwiatkowski DJ, Williams DA: Hematopoietic cell regulation by Rac1 and Rac2 guanosine triphosphatases. Science 2003;302:445-449.

154 Yang FC, Atkinson SJ, Gu Y, Borneo JB, Roberts AW, Zheng Y, Pennington J, Williams DA: Rac and Cdc42 GTPases control hematopoietic stem cell shape, adhesion, migration, and mobilization. Proc Natl Acad Sci U S A 2001;98:5614-5618.

155 Guan JL: Cell biology. Integrins, rafts, Rac, and Rho. Science 2004;303:773-774.

156 Gomez-Mouton C, Lacalle RA, Mira E, JimenezBaranda S, Barber DF, Carrera AC, Martinez AC, Manes S: Dynamic redistribution of raft domains as an organizing platform for signaling during cell chemotaxis. J Cell Biol 2004;164:759-768.

157 Hoggatt J, Singh P, Sampath J, Pelus LM: Prostaglandin E2 enhances hematopoietic stem cell homing, survival, and proliferation. Blood 2009;113:5444-5455.

158 North TE, Goessling W, Walkley CR, Lengerke C, Kopani KR, Lord AM, Weber GJ, Bowman TV, Jang IH, Grosser T, Fitzgerald GA, Daley GQ, Orkin SH, Zon LI: Prostaglandin E2 regulates vertebrate haematopoietic stem cell homeostasis. Nature 2007;447:10071011.
159 Pelus LM, Broxmeyer HE, Kurland JI, Moore MA: Regulation of macrophage and granulocyte proliferation. Specificities of prostaglandin E and lactoferrin. J Exp Med 1979;150:277-292.

160 Pelus LM, Broxmeyer HE, Moore MA: Regulation of human myelopoiesis by prostaglandin E and lactoferrin. Cell Tissue Kinet 1981;14:515-526.

161 Taetle R, Koessler A: Effects of cyclic nucleotides and prostaglandins on normal and abnormal human myeloid progenitor proliferation. Cancer Res 1980;40: 1223-1229.

162 Hoggatt J, Mohammad KS, Singh P, Hoggatt AF, Chitteti BR, Speth JM, Hu P, Poteat BA, Stilger KN, Ferraro F, Silberstein L, Wong FK, Farag SS, Czader M, Milne GL, Breyer RM, Serezani CH, Scadden DT, Guise TA, Srour EF, Pelus LM: Differential stem- and progenitor-cell trafficking by prostaglandin E2. Nature 2013;495:365-369.

163 Zirafi O, Kim KA, Standker L, Mohr KB, Sauter D, Heigele A, Kluge SF, Wiercinska E, Chudziak D, Richter R, Moepps B, Gierschik P, Vas V, Geiger H, Lamla M, Weil T, Burster T, Zgraja A, Daubeuf F, Frossard N, Hachet-Haas M, Heunisch F, Reichetzeder C, Galzi JL, Perez-Castells J, Canales-Mayordomo A, Jimenez-Barbero J, Gimenez-Gallego G, Schneider M, Shorter J, Telenti A, Hocher B, Forssmann WG, Bonig H, Kirchhoff F, Munch J: Discovery and characterization of an endogenous CXCR4 antagonist. Cell Rep 2015;11: 737-747.

164 Yamamoto K, Kawakubo T, Yasukochi A, Tsukuba T: Emerging roles of cathepsin $\mathrm{E}$ in host defense mechanisms. Biochim Biophys Acta 2012;1824:105-112.

165 Appelqvist H, Waster P, Kagedal K, Ollinger K: The lysosome: from waste bag to potential therapeutic target. J Mol Cell Biol 2013;5:214-226.

166 Winkler IG, Hendy J, Coughlin P, Horvath A, Levesque JP: Serine protease inhibitors serpinal and serpina3 are down-regulated in bone marrow during hematopoietic progenitor mobilization. J Exp Med 2005; 201:1077-1088.

167 Michelsen K: Determination in inulin, albumin and erythrocyte spaces in the bone marrow of rabbits. Acta Physiol Scand 1969;77:28-35. 